\title{
Activated carbon from termite feces impregnated with silver: Preparation and evaluation of antimicrobial activity and ecotoxicity
}

\author{
Carvão activado obtidos de excremetos de cupim e impregnado com prata: Preparação e avaliação \\ da actividade antimicrobiana e ecotoxicidade
}

\section{Giovanna Manesco ${ }^{1}$, Carla Albertina Demarchi ${ }^{1}$, Alexandre Bella Cruz ${ }^{1}$, Jean Felipe Fossá Calisto ${ }^{2}$, Rafael Martello ${ }^{2}$, Jacir Dal Magro ${ }^{2}$, and Clovis Antonio Rodrigues ${ }^{1 *}$}

\author{
${ }^{1}$ Núcleo de Investigações Químico-Farmacêuticas (NIQFAR). Universidade do Vale do Itajaí (UNIVALI). Itajaí. 88302-202 \\ Santa Catarina. Brazil; \\ ${ }^{2}$ Programa de Pós-Graduação em Ciências Ambientais, Universidade Comunitária da Região de Chapecó (Unochapecó), PO \\ Box 1141, Chapecó, SC, Brazil
}

*corresponding author: crodrigues@univali.br

\begin{abstract}
Silver has a potent antimicrobial action, but its use is still restricted due to toxicity and aggregation problems. Impregnation with active carbon (AC) has been suggested as an alternative to solve this problem. In this study, termite feces were used to prepare composites containing silver nanoparticles and AC. Reducing agents and different amounts of $\mathrm{H}_{2} \mathrm{SO}_{4}$ and silver were used. Antimicrobial activity was assessed using the minimum inhibitory concentration (MIC) and the kinetics of microbial growth of $S$. aureus, E. coli and C. albicans. Phytotoxicity and acute toxicity were assessed for Cucumis sativus and Artemia salina. The composites that presented MIC $500 \mu \mathrm{g} / \mathrm{mL}$ for $S$. aureus and E. coli were $\mathrm{AC} 25 \mathrm{Ag}(6 \mu \mathrm{g} / \mathrm{mL} \mathrm{Ag})$ and $\mathrm{AC} 25 \mathrm{AgB}(78 \mu \mathrm{g} / \mathrm{mL} \mathrm{Ag})$, respectively. AC6AgS showed antimicrobial activity in $C$. albicans with MIC of $500 \mu \mathrm{g} / \mathrm{mL}(23 \mu \mathrm{g} / \mathrm{mL} \mathrm{Ag})$. AC25AgB inhibited the growth of $S$. aureus and E. coli for 48 and $32 \mathrm{~h}$, respectively. At a concentration of $10 \mathrm{~g} / \mathrm{L}$, the compounds showed deleterious effects on seedling germination and elongation and on the chlorophyll synthesis of $C$. sativus. The composites showed no toxicity to A. salina. Based on these results, $\mathrm{AC} 25 \mathrm{AgB}$ has the potential to be used in water disinfection.
\end{abstract}

Keywords: Activated carbon, silver nanoparticles, antimicrobial activity, toxicity, Cryptotermes brevis

\section{Resumo}

A prata tem uma acção antimicrobiana potente, mas seu uso ainda é restrito devido a problemas de toxicidade e agregação. A impregnação no carvão activo (CA) tem sido aparentada como alternativa para resolver este problema. Neste estudo, fezes de cupins foram usadas para preparar compósitos contendo nanopartículas de prata e CA. Utilizaram-se agentes redutores e diferentes quantidades de $\mathrm{H}_{2} \mathrm{SO}_{4}$ e prata. A actividade antimicrobiana foi avaliada utilizando a concentração inibitória mínima (CIM) e a cinética do crescimento microbiano de $S$. aureus, E. coli e $C$. albicans. A fitotoxicidade e a toxicidade aguda foram avaliadas para Cucumis sativus e Artemia salina. A fitotoxicidade e a toxicidade aguda foram avaliadas para Cucumis sativus e Artemia salina. Os compósitos que apresentaram CIM $500 \mu \mathrm{g} / \mathrm{mL}$ para $S$. aureus e E. coli foram CA25Ag $(6 \mu \mathrm{g} / \mathrm{mL} \mathrm{Ag})$ e CA25AgB $(78 \mu \mathrm{g} / \mathrm{mL} \mathrm{Ag})$, respectivamente. O CA6AgS mostrou actividade antimicrobiana em C. albicans com CIM de $500 \mu \mathrm{g} / \mathrm{mL}(23 \mu \mathrm{g} / \mathrm{mL} \mathrm{Ag})$. O CA25AgB inibiu o crescimento de $S$. aureus e $E$. coli por 48 e $32 \mathrm{~h}$, respectivamente. Na concentração de $10 \mathrm{~g} / \mathrm{L}$ os compostos mostraram efeitos deletérios sobre germinação e alongamento de plântulas e na síntese de clorofila da C. sativus. Os compósitos não apresentaram toxicidade para A. salina. Com bases nos resultados podemos dizer que, o CA25AgB apresenta potencial para ser utilizado na desinfecção de água.

Palavras-chave: Carvão activo, nanopartículas de prata, actividade antimicrobiana, toxicidade, Cryptotermes brevis 


\section{Introduction}

Recent years have seen a breakthrough in the development and research of nanotechnology and nanomaterials. Metal nanoparticles have wide functionality in a range of application areas, such as electronics, biological sensors, drugs, and water treatments. One of the recent advances is the development of silver nanoparticles (AgNPs), which have attracted much attention in scientific research due to their physical, chemical, and biological characteristics $(1,2)$. In recent years, some nanomaterials impregnated with AgNPs have been reported to have superior bactericidal properties, and are widely used to water disinfectants (3-8).

The antibacterial effect of silver has been explored since ancient civilizations. The exact mechanism of silver compounds against microorganisms is not yet fully understood, but the most likely mechanism is the direct interaction with the cell membrane and DNA, and the triggering of biochemical cascades that lead to the production of free radicals, changing the permeability of the cell membrane $(9,10)$.

An important issue in the antibacterial activity of AgNPs is the release of $\mathrm{Ag}^{+}$ions due to their oxidation in the presence of water and aggregation in their dispersion due to the attractive forces between the particles and the surface. To prevent aggregation and maintain an effective antibacterial effect, the incorporation of the AgNPs into stabilizing materials has been extensively investigated $(11,12)$. AgNPs can be synthesized by several approaches, including physical, chemical, and biological. Chemical synthesis involves the reduction of the silver ion from silver salts, such as silver nitrate, by means of reducing agents. The most commonly used reducing agents are borohydride, sodium citrate, ascorbic acid, alcohol and hydrazine compounds. The reduction of silver ions $\left(\mathrm{Ag}^{+}\right)$in aqueous solution leads to the formation of silver atoms $\left(\mathrm{Ag}^{0}\right)$, followed by the formation of oligomeric clusters (13-15).

Considerable attention has been paid in recent years to impregnation of AgNPs in activated carbon (AC), a widely used material for water treatment worldwide. $\mathrm{AC}$ can be prepared from various organic and inorganic materials. The most commonly used are coal, rice husks, coconut, and wood, or any lignocellulosic material (16). AC is known to be an adsorbent material capable of removing a wide variety of organic and inorganic matter due to its main characteristics, which include a large surface area, a high degree of microporosity, and the presence of a broad spectrum of functional groups (17). It can come from different materials, provided the material has high carbon content. In this process, vari-

\section{Introdução}

Nos últimos anos, houve um avanço no desenvolvimento e pesquisa de nanotecnologia e nanomateriais. Nanopartículas de metal têm ampla funcionalidade em diversas áreas de aplicação, como electrónicos, sensores biológicos, medicamentos e tratamentos de água. Um dos recentes avanços é o desenvolvimento de nanopartículas de prata (NPAg), que têm atraído muita atenção em pesquisas científicas devido às suas características físicas, químicas e biológicas $(1,2)$. Nos últimos anos, tem sido relatado na literatura que alguns nanomateriais impregnados com NPAg têm propriedades bactericidas superiores, são amplamente utilizados para desinfectantes de água (3-8).

$\mathrm{O}$ efeito antibacteriano da prata tem sido explorado desde civilizações antigas. O mecanismo exacto dos compostos de prata contra os microrganismos ainda não está totalmente esclarecido, mas o mecanismo mais provável é interacção directa com a membrana celular e o ADN e o desencadeamento de cascatas bioquímicas que levam à produção de radicais livres, alterando a permeabilidade da membrana celular $(9,10)$.

Uma questão importante na actividade antibacteriana dos NPAg é a libertação de ião $\mathrm{Ag}^{+}$devido à sua oxidação na presença de água e agregação na sua dispersão devido às forças atractivas entre as partículas e a superfície. Para evitar a agregação e manter um efeito antibacteriano eficaz, a incorporação dos NPAg nos materiais estabilizadores tem sido extensivamente investigada $(11,12)$.

Os NPAg podem ser sintetizados por várias abordagens, incluindo física, química e biológica. A síntese química envolve a redução do ião prata dos sais de prata, como o nitrato de prata, por meio de agentes redutores. Os agentes redutores mais usados são compostos de borohidreto, citrato de sódio, ácido ascórbico, álcool e hidrazina. A redução de iões de prata $\left(\mathrm{Ag}^{+}\right)$em solução aquosa leva à formação de átomos de prata $\left(\mathrm{Ag}^{0}\right)$, seguida pela formação de aglomerados oligoméricos (1315).

Nos últimos anos, foi prestada atenção considerável à impregnação de NPAg em carvão activado (CA), um material amplamente utilizado para tratamento de água em todo o mundo. A CA pode ser preparada a partir de vários materiais orgânicos e inorgânicos. Os mais utilizados são carvão, casca de arroz, coco e madeira ou qualquer material lenho celulósico (16). Sabe-se que a CA é um material adsorvente capaz de remover uma grande variedade de matéria orgânica e inorgânica devido às suas principais características, que incluem uma grande área superficial, um alto grau de micropo- 
ous precursors may be used to incorporate silver, such as commercial AC $(18,19)$, corncob $(20)$, sugarcane bagasse (21), and AC containing nutshell (17), coconut shell (22), and palm shell (23).

Based on this context, this study aimed to impregnate AgNPs in activated carbon prepared from organic matter (Cryptotermes brevis feces), using different reducing agents and different amounts of silver. The antimicrobial effect of these materials on the bacteria Staphylococcus aureus (gram-positive) and Escherichia coli (gram-negative) and the yeast Candida albicans were evaluated by determining the minimum inhibitory concentration (MIC) and microbial growth kinetics. In addition, the phytotoxicity in the germination and growth of Cucumis sativus and the toxicity of Artemia salina were analyzed to determine if the material would be safe to aquatic and plant life and support its potential use for water disinfection.

\section{Material and Methods}

\section{Material}

Feces of Cryptotermes brevis fed with Pinus sp. were collected at the Biopolymers Laboratory of the Universidade do Vale do Itajaí, Brazil. All chemical reagents (grade P.A) were from Vetec, Inc. (São Paulo, SP, Brazil) and were used without purification.

\section{Preparation of composites}

\section{Preparation of activated carbon}

For the synthesis of activated carbon, termite feces were treated with $98 \% \mathrm{H}_{2} \mathrm{SO}_{4}$ at a ratio of $1: 1,1: 2,1: 4$ and 1:6 $\left(\mathrm{H}_{2} \mathrm{SO}_{4}\right.$ : termite feces, w/w). Briefly, the mixture was shaken gently in a fume hood and placed in an oven at $150{ }^{\circ} \mathrm{C}$ for $24 \mathrm{~h}$ to achieve low-temperature complete chemical carbonization of the organic material. After carbonization, the materials were mixed with deionized water and agitated for $2 \mathrm{~h}$ to remove the unreacted acid (until negative sulfate test, using $\mathrm{BaCl} 2$ (1\% $\mathrm{w} / \mathrm{w}$ solution) as sulfate indicator reagent). Next, the dried solid was treated at a temperature of $600{ }^{\circ} \mathrm{C}$ for 4 $\mathrm{h}$ in muffle furnace, in the absence of oxygen. The resulting materials were named $\mathrm{AC} 50, \mathrm{AC} 25, \mathrm{AC} 12$ and AC6 respectively. rosidade e a presença de um amplo espectro de grupos funcionais (17) Pode vir de materiais diferentes, desde que o material tenha alto teor de carbono. Nesse processo, vários precursores podem ser usados para incorporar prata, como CA comercial $(18,19)$, sabugo de milho (20), bagaço de cana (21) e casca de noz contendo CA (17), casca de coco (22) e casca de palma (23).

Com base nesse contexto, este estudo teve como objectivo impregnar NPAg em carvão activado preparado a partir de matéria orgânica (Cryptotermes brevis fezes), utilizando diferentes agentes redutores e diferentes quantidades de prata. O efeito antimicrobiano desses materiais sobre as bactérias Staphylococcus aureus (gram-positivo) e Escherichia coli (gram-negativo) e a levedura Candida albicans foram avaliados através da determinação da concentração inibitória mínima (CIM) e da cinética de crescimento microbiano. Além disso, a fitotoxicidade na germinação e crescimento de Cucumis sativus e a toxicidade de Artemia salina foram analisadas para determinar se o material seria seguro para a vida aquática e vegetal e apoiar seu potencial uso na desinfecção da água.

\section{Material e Métodos}

\section{Material}

Fezes de Cryptotermes brevis alimentadas com Pinus sp. foram coletadas no Laboratório de Biopolímeros da Universidade do Vale do Itajaí, Brasil. Todos os reagentes químicos (grau P.A) eram da Vetec, Inc. (São Paulo, Brasil) e foram utilizados sem purificação.

\section{Preparação dos compósitos}

\section{Preparação do carvão ativo (CA)}

Para a preparação do $\mathrm{CA}$, fezes de cupins foram tratadas com $98 \%$ de $\mathrm{H}_{2} \mathrm{SO}_{4}$ na proporção de 1:1, 1:2, 1:4 e 1:6 $\left(\mathrm{H}_{2} \mathrm{SO}_{4}\right.$ : fezes de cupim, $(\mathrm{m} / \mathrm{m})$. Resumidamente, a mistura foi agitada suavemente em exaustor e colocada em forno a $150{ }^{\circ} \mathrm{C}$ por $24 \mathrm{~h}$ para obter uma carbonização química completa em baixa temperatura do material orgânico. Após a carbonização, os materiais foram misturados com água desionizada e agitados por $2 \mathrm{~h}$ para remover o ácido que não reagiu (até teste de sulfato negativo, usando $\mathrm{BaCl} 2$ (solução a $1 \% \mathrm{~m} / \mathrm{m}$ ) como reagente indicador de sulfato). Em seguida, o sólido seco foi tratado a uma temperatura de $600{ }^{\circ} \mathrm{C}$ durante $4 \mathrm{~h}$ em mufla, na ausência de oxigenio. Os materiais resultantes foram designados CA50, CA 25, CA12 e CA6. 


\section{Incorporation of silver nanoparticles}

\section{Synthesis without reducing agent}

The AC6, AC12, AC25 and AC50 (2.0 g) were dispersed in $50 \mathrm{~mL}$ of distilled water. The $\mathrm{AgNO}_{3}(1.0 \mathrm{~g})$ was solubilized separately in $100 \mathrm{~mL}$ water, added to the mixture, and stirred for 10 minutes. The $\mathrm{pH}$ was adjusted to 10 with concentrated aqueous sodium hydroxide and the mixture stirred on a hot plate with magnetic stirring at $80{ }^{\circ} \mathrm{C}$ for $60 \mathrm{~min}$, protected from light (24). Finally, the mixture was washed with distilled water and dried under vacuum for $24 \mathrm{~h}$. The resulting composites were named AC6Ag, AC12Ag, AC25Ag and AC50Ag.

\section{Synthesis with $\mathrm{NaBH}_{4}$}

The AC6, AC12, AC25 and AC50 (2.0 g) was dispersed in $50 \mathrm{~mL}$ of distilled water. The $\mathrm{AgNO}_{3}(1.0 \mathrm{~g})$ was solubilized separately in $100 \mathrm{~mL}$ water, added to the mixture, and stirred for 10 minutes. After the addition of $\mathrm{NaBH}_{4}(0.2 \mathrm{~g})$, the mixture stirred with magnetic stirring for $60 \mathrm{~min}$, protected from light. Finally, the mixture was washed with distilled water and dried under vacuum for $24 \mathrm{~h}(25)$. The resulting composites were named AC6AgB, AC12AgB, AC25AgB, AC50AgB.

\section{Synthesis with sucrose}

The AC6, AC12, AC25, and AC50, (2.0 g) preparation were dispersed in $50 \mathrm{~mL}$ of distilled water. The $\mathrm{AgNO}_{3}$ $(1.0 \mathrm{~g})$ was solubilized separately was solubilized separately in $100 \mathrm{~mL}$ water, added to the mixture and, stirred for 10 minutes. Sucrose (10 g solubilized in a sufficient amount of distilled water) was then added. The $\mathrm{pH}$ was adjusted to 10 with concentrated aqueous sodium hydroxide. The mixture stirred on a hot plate with magnetic stirring at $80{ }^{\circ} \mathrm{C}$ for $60 \mathrm{~min}$, protected from light. Finally, the mixture was washed with distilled water and dried under vacuum for $24 \mathrm{~h}$ (26). The resulting composites were named AC6AgS and AC12AgS.

\section{Characterization}

\section{pH on Point of zero charge $\left(\mathrm{pH}_{p z \mathrm{c}}\right)$}

A suspension of $100 \mathrm{mg} \mathrm{AC}$ in $20 \mathrm{~mL}$ of distilled water in the presence of $50 \mathrm{mM}$ of $\mathrm{NaCl}$ was shaken for $24 \mathrm{~h}$ at $25{ }^{\circ} \mathrm{C}$. The $\mathrm{pH}$ of the suspension was then adjusted in the range 4 to 12 with either diluted $\mathrm{HCl}$ or $\mathrm{NaOH}$ solution, using a $\mathrm{pH}$ meter, and was considered the initial $\mathrm{pH}$ of the suspensions. The final $\mathrm{pH}$ of the suspension was measured after the $24 \mathrm{~h}$ equilibration. The PZC of the adsorbents were determined from the plot of $\mathrm{pH}_{\text {final- }}$

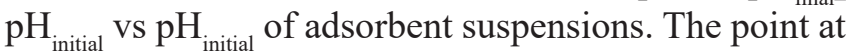

Incorporação das nanoparticulas de prata

\section{Preparação sem agente redutor}

CA6, CA12, CA25 e CA50 (2,0 g) foram dispersos em $50 \mathrm{~mL}$ de água destilada. $\mathrm{O} \mathrm{AgNO}_{3}(1,0 \mathrm{~g})$ foi solubilizado separadamente em $100 \mathrm{~mL}$ de ágaus, adicionado à mistura e agitado durante 10 minutos. $\mathrm{O} \mathrm{pH}$ foi ajustado para 10 com hidróxido de sódio aquoso concentrado e a mistura foi agitada magneticamente em placa quente à $80 \mathrm{oC}$ e protegida da luz durante $60 \mathrm{~min}$ (24). Finalmente, a mistura foi lavada com água destilada e seca sob vácuo por $24 \mathrm{~h}$. Os compósitos resultantes foram denominados como CA12Ag, CA25Ag e CA50Ag.

\section{Preparação com $\mathrm{NaBH}_{4}$}

CA6, CA12, CA25 e CA50 (2,0 g) foram dispersos em $50 \mathrm{~mL}$ de água destilada. $\mathrm{O} \mathrm{AgNO}_{3}(1,0 \mathrm{~g})$ foi solubilizado separadamente, adicionado à mistura e agitado durante 10 minutos. Foi adicionado $\mathrm{NaBH}_{4}(0,2 \mathrm{~g})$ e a mistura foi agitada foi agitada magneticamente e protegida da luz durante $60 \mathrm{~min}$. Finalmente, a mistura foi lavada com água destilada e seca sob vácuo por $24 \mathrm{~h}$ (25). Os compósitos resultantes foram denominados como CA6AgB, CA12AgB, CA25AgB e CA50AgB.

\section{Preparação com sacarose}

CA6, CA12, CA25 e CA50 (2,0 g) foram dispersos em $50 \mathrm{~mL}$ de água destilada. $\mathrm{O} \mathrm{AgNO}_{3}(1,0 \mathrm{~g})$ foi solubilizado separadamente, adicionado à mistura e agitado durante 10 minutos. Em seguida, foi adicionada sacarose (10 g), após ter sido solubilizada em uma quantidade suficiente de água destilada. $\mathrm{O}$ pH foi ajustado para 10 com hidróxido de sódio aquoso concentrado e a mistura foi agitada magneticamente em placa quente à $80{ }^{\circ} \mathrm{C}$ e protegida da luz durante $60 \mathrm{~min}$. Finalmente, a mistura foi lavada com água destilada e seca sob vácuo por 24 h (26). Os compósitos resultantes foram denominados como CA6AgS, CA12AgS, CA25AgS e CA50AgS.

\section{Carcaterização}

\section{Ponto de carga zero do $\mathrm{pH}$ ( $\mathrm{pH}_{\mathrm{pc}}$ )}

Uma suspensão de $100 \mathrm{mg}$ de CA em $20 \mathrm{~mL}$ de água destilada foi agitada por 24 horas a $25{ }^{\circ} \mathrm{C}$ na presença de $\mathrm{NaCl} 50 \mathrm{mM}$. O pH da suspensão foi então ajustado na faixa de 4 a 12 com solução diluída de $\mathrm{HCl}$ ou $\mathrm{NaOH}$, usando um medidor de $\mathrm{pH}$, e foi considerado o pH inicial das suspensões. $\mathrm{O}$ pH final da suspensão foi medido após o equilíbrio de $24 \mathrm{~h}$. O PCZ dos adsorventes foi determinado a partir do gráfico de $\mathrm{pH}_{\text {final- }}$ $\mathrm{pH}_{\text {initial }}$ versus $\mathrm{pH}_{\text {inicial }}$ das suspensões de adsorventes. $\mathrm{O}$ 
which $\mathrm{pH}$ becomes zero was named pHpzc (27). The experiments were carried out in triplicate.

\section{Specific Surface Area (SSA)}

The SSA was determined by the methylene blue (MB) adsorption method; $100 \mathrm{mg}$ of $\mathrm{AC}$ was mixed with 20 $\mathrm{mL}$ of MB solution $(12.5-150 \mathrm{mg} / \mathrm{L})$ and the suspension was shaken for $2 \mathrm{~h}$ at $25{ }^{\circ} \mathrm{C}$. Five $\mathrm{mL}$ of the solution was then removed, and centrifuged. The remnant concentration of $\mathrm{MB}$ in the fluid was determined using a UV/Vis spectrophotometer (Jasco V-630, Easton, MD, USA) at a wavelength of $655 \mathrm{~nm}$. The SSA was derived from the point of complete cation replacement determined on the titration curve. When the curve deviates more than $45^{\circ}$ from a straight line, this indicates that additional MB cannot be completely absorbed by the adsorbent. Thus, the SSA is calculated by the following equation [1], based on the amount of adsorbed MB:

$$
S S A=\frac{m_{M B}}{319.87} \times A_{v} x A_{M B} x \frac{1}{m_{S}}
$$

where Av is Avogadro's number (6.02 x 10 $\left.10^{23} / \mathrm{mol}\right)$, and $\mathrm{AMB}$ is the area covered by one MB molecule (130 $\AA^{2}$ ), mMB is the mass of the adsorbed MB at the point of complete cation replacement, and $\mathrm{ms}$ is the mass of the adsorbent (28).

\section{Functional active groups}

The functional groups on the surface of $A C$ were characterized by the Boehm method, as follows: $50 \mathrm{mg}$ of $\mathrm{AC}$ was dispersed in $20 \mathrm{~mL}$ of $0.05 \mathrm{M} \mathrm{NaHCO}_{3}, 0.025 \mathrm{M}$ $\mathrm{Na}_{2} \mathrm{CO}_{3}, 0.05 \mathrm{M} \mathrm{NaOH}, 0.05 \mathrm{M} \mathrm{HCl}$, and shaken for 24 hours. Next, the samples were centrifuged and titrated in triplicate with $0.1 \mathrm{M} \mathrm{NaOH}$ or $0.1 \mathrm{M} \mathrm{HCl}$, depending on the initial solution used. The number of groups on the surface of the adsorbent was analyzed as follows: $\mathrm{NaHCO}_{3}$ (carboxylic groups), $\mathrm{Na}_{2} \mathrm{CO}_{3}$ (carboxylic groups and lactones), $\mathrm{NaOH}$ (carboxylic groups, lactones, and phenolic groups) and $\mathrm{HCl}$ (basic sites) (29).

\section{Iodine number}

The $\mathrm{I}_{2}$ number $(\mathrm{mg} / \mathrm{g})$ for the $\mathrm{AC}$ was determined as described in the literature (30). Approximately $150 \mathrm{mg}$ of $\mathrm{AC}$ was placed in a $250 \mathrm{~mL}$ dry Erlenmeyer flask, fully wetted by boiling for $30 \mathrm{~s}$ with $10 \mathrm{~mL}$ of dilute $\mathrm{HCl}(0.04 \mathrm{M})$ and subsequently cooled. Next, $20 \mathrm{~mL}$ of $\mathrm{I}_{2}$ solution $(0.05 \mathrm{M})$ was added to the mixture, which was then shaken for $30 \mathrm{~min}$. The resulting solution was filtered, and $50 \mathrm{~mL}$ of the filtrate was titrated with sodium thiosulfate solution $(0.01 \mathrm{M})$, using starch as an indicator. The remaining concentration of $\mathrm{I}_{2}$ in the solu- ponto em que o $\mathrm{pH}$ se torna zero foi nomeado $\mathrm{pHpcz}$ (27). Os experimentos foram realizados em triplicata.

\section{Área superficial especifica (ASE)}

A ASE foi determinada pelo método de adsorção do azul de metileno (AM); $100 \mathrm{mg}$ de CA foram misturados com $20 \mathrm{~mL}$ de solução AM $(12,5-150 \mathrm{mg} / \mathrm{L})$ e a suspensão foi agitada durante $2 \mathrm{~h}$ a $25^{\circ} \mathrm{C}$. Em seguida, $5 \mathrm{~mL}$ da solução foram removidos e centrifugados. A concentração remanescente de AM no fluido foi determinada por um espectrofotometro Jasco V-630 UV/Vis a um comprimento de onda de $655 \mathrm{~nm}$. A ASE foi derivada do ponto de substituição completa do catião determinado na curva de titulação. Quando a curva se desvia mais de $45^{\circ}$ de uma reta, isso significa que nenhum AM adicional pode ser completamente adsorvido pelo adsorvente. Assim, a ASE é calculada pela seguinte equação [1], com base na quantidade de AM adsorvida:

$$
S S A=\frac{m_{M B}}{319,87} x A_{v} x A_{M B} x \frac{1}{m_{s}}
$$

onde Av é o número de Avogadro (6,02 x 10 $23 / \mathrm{mol})$ e AMB é a área coberta por uma molécula de AM (130 $\AA^{2}$ ), mMB é a massa do AM adsorvido no ponto de substituição completa do catião e ms é a massa do adsorvente (28).

\section{Grupos funcionais ativos}

Os grupos funcionais na superfície do CA foram caracterizados pelo método de Boehm, da seguinte forma: $50 \mathrm{mg}$ de CA foram dispersos em $20 \mathrm{~mL}$ de $\mathrm{NaHCO}_{3}$ $0,05 \mathrm{M}, \mathrm{Na}_{2} \mathrm{CO}_{3} 0,025 \mathrm{M}, \mathrm{NaOH} 0,05 \mathrm{M}, \mathrm{NaOH} 0,05$ $\mathrm{M}, \mathrm{HCl} 0,05 \mathrm{M}$ e agitados durante 24 horas. Em seguida, as amostras foram centrifugadas e tituladas em triplicado com $\mathrm{NaOH} 0,1 \mathrm{M}$ ou $\mathrm{HCl} 0,1 \mathrm{M}$, dependendo da solução inicial utilizada. O número de grupos na superfície do adsorvente foi analisado da seguinte forma: $\mathrm{NaHCO}_{3}$ (grupos carboxílicos), $\mathrm{Na}_{2} \mathrm{CO}_{3}$ (grupos carboxílicos e lactonas), $\mathrm{NaOH}$ (grupos carboxílicos, lactonas e grupos fenólicos) e $\mathrm{HCl}$ (locais básicos) (29).

\section{Número de iodo}

O número de $\mathrm{I}_{2}(\mathrm{mg} / \mathrm{g})$ para CA foi determinado conforme descrito na literatura (30). Cerca de $150 \mathrm{mg}$ de CA foi colocado em um balão Erlenmeyer seco de 250 $\mathrm{mL}$, umedecido completamente por ebulição durante $30 \mathrm{~s}$ com $10 \mathrm{~mL}$ de $\mathrm{HCl}$ diluído $0,04 \mathrm{M}$ e subsequentemente resfriado. Em seguida, $20 \mathrm{~mL}$ de solução de $\mathrm{I}_{2}$ $(0,05 \mathrm{M})$ foram adicionados à mistura, que foi agitada durante $30 \mathrm{~min}$. A solução resultante foi filtrada e 50 $\mathrm{mL}$ do filtrado foram titulados com solução de tios- 
tion was calculated from the total volume of sodium thiosulfate used.

\section{Amount of silver impregnated}

The amount of silver impregnated on AC was determined by atomic absorption spectrophotometry (AAS Perkin Elmer model Analyst 800, Billerica, MA, USA). The calibration curve was prepared by serial dilutions of the $1000 \mathrm{mg} / \mathrm{L}$ stock solution (Assurance Grade Interference Check Standard/SPEX CertiPrep ${ }^{\circledR}$, Metuchen, NJ, USA)

\section{Antimicrobial assays}

Determination of minimum inhibitory concentration (MIC)

The minimum inhibitory concentrations (MIC) of the materials for Staphylococcus aureus (ATCC 25923), Eschechia coli (ATCC 25922) and Candida albicans (ATCC 10231) were determined in 96-well microtiter plates using a standard two-fold broth microdilution of the antibacterial agents, following the guidelines of the Clinical and Laboratory Standards Institute (31). Serial dilutions of the antibacterial material were performed in Mueller-Hinton (bacteria) and Sabouraund (yeast) broths, which were inoculated with a standardized number of organisms $\left(1.5 \times 10^{5} \mathrm{UFC} / \mathrm{mL}\right)$ and incubated overnight at $37{ }^{\circ} \mathrm{C}$. The concentrations tested ranged from 1000 to $1.95 \mu \mathrm{g} / \mathrm{mL}$. Cell growth was determined by observing the turbidity of the culture. The lowest concentration of the materials at which no visual turbidity could be observed was considered to be the MIC of the antimicrobial materials.

\section{Microbial growth kinetics}

Suspensions $(50 \mathrm{~mL})$ of $S$. aureus $\left(1.5 \times 10^{6} \mathrm{UFC} / \mathrm{mL}\right)$, E. coli $\left(1.5 \times 10^{6} \mathrm{UFC} / \mathrm{mL}\right)$ and C. albicans $\left(1.5 \times 10^{4}\right.$ $\mathrm{UFC} / \mathrm{mL}$ ) were prepared in Mueller-Hinton (bacterias) and Sabouraund (yeast) broths containing different concentrations of composites, according to the MIC, and incubated at $37^{\circ} \mathrm{C}$ with continuous agitation $(120 \mathrm{rpm})$. After a pre-determined incubation time, the antimicrobial efficacy was determined by measuring OD at 600 nm. sulfato de sódio $(0,01 \mathrm{M})$, utilizando amido como indicador. A concentração remanescente de $\mathrm{I}_{2}$ na solução foi calculada a partir do volume total de tiossulfato de sódio utilizado.

\section{Quantidade de prata impregnada}

A quantidade de prata impregnada em CA foi determinada por espectrofotometria de absorção atómica (AAS Perkin Elmer model Analyst 800). A curva de calibração foi preparada por diluições em série da solução estoque $1000 \mathrm{mg} / \mathrm{L}$ (Assurance Grade Interference Check Standard/SPEX CertiPrep $\left.{ }^{\circledR}\right)$.

\section{Ensaios antimicrobianos}

\section{Determinação da concentração inibitória mínima (CIM)}

As concentrações inibitórias mínimas (CIM) dos materiais para Staphylococcus aureus (ATCC 25923), Escherichia coli (ATCC 25922) e Candida albicans (ATCC 10231) foram determinadas em placas de micro titulação de 96 poços usando uma micro diluição padrão de 2 vezes em caldo dos agentes antibacterianos, seguindo as directrizes do Instituto de Padrões Clínicos e Laboratoriais (31). Diluições seriadas do material antibacteriano foram realizadas em caldos Mueller-Hinton (bactérias) e Sabouraund (levedura), que foram inoculados com um número padronizado de organismos $(1,5$ x $10^{5} \mathrm{UFC} / \mathrm{mL}$ ) e incubados durante a noite a $37^{\circ} \mathrm{C}$. As concentrações testadas variaram de 1000 a $1,95 \mu \mathrm{g} / \mathrm{mL}$. O crescimento celular foi determinado pela observação da turbidez da cultura. A menor concentração dos materiais nos quais não foi observada turbidez visual foi considerada a CIM dos materiais antimicrobianos.

\section{Cinética de crescimento microbiano}

Suspensões (50 mL) de $S$. aureus $\left(1,5 \times 10^{6} \mathrm{UFC} / \mathrm{mL}\right)$, E. coli $\left(1,5 \times 10^{6} \mathrm{UFC} / \mathrm{mL}\right)$ e C. albicans $\left(1,5 \times 10^{4}\right.$ $\mathrm{UFC} / \mathrm{mL}$ ) foram preparadas em Mueller-Hinton (bactérias) e caldos Sabouraund (levedura) contendo diferentes concentrações de compósitos, de acordo com a CIM, e incubados a $37^{\circ} \mathrm{C}$ com agitação contínua (120 rpm). Após um tempo de incubação predeterminado, a eficácia antimicrobiana foi determinada pela medição da DO a $600 \mathrm{~nm}$. 
Phytotoxic assays with Cucumis sativus

\section{Seed germination tests}

Cucumis sativus seeds were incubated in Petri dishes containing one qualitative filter paper grade 1 . Ten seeds, geometrically scaled, were incubated with $5 \mathrm{~mL}$ of distilled water (control) or respective AC suspension at concentrations of $1,10,100,1000$, and 10,000 $\mathrm{mg} / \mathrm{L}$, for $7 \mathrm{~d}$ at $25^{\circ} \mathrm{C}$ in the dark. The experiments were performed in triplicate. The number of germinated seeds was counted, and the root length was measured. Sequentially germinated seeds were incubated at $60{ }^{\circ} \mathrm{C}$ for $48 \mathrm{~h}$ to determine the dry weights. The seedlings were grouped and weighed together in each replicate and the results were normalized for the number of germinated seeds.

To provide a comprehensive interpretation, seed germination, and root elongation can be combined in a germination index (GI), according to equation [2]

$$
G I(\%)=\left(G_{s} L_{s} / G_{c} L_{c}\right) \times 100
$$

where Gs and Ls are seed germination (\%) and root elongation ( $\mathrm{mm}$ ) for the sample; Gc and Lc the corresponding control values (32).

Seedling elongation inhibition (SEI \%) provides information about the inhibition (positive values) and stimulation (negative values) of the seed germination. SEI $(\%)$ can be calculated by the equation:

$$
\operatorname{SEI}(\%)=\frac{L_{c}-L_{s}}{L_{c}} \times 100
$$

where Lc and Ls are root elongation ( $\mathrm{mm}$ ) for the control and sample.

\section{Measurement of chlorophyll content}

Cucumis sativus seeds were kept in contact with $\mathrm{AC}$ at a concentration of $10,000 \mathrm{mg} / \mathrm{L}$ in the dark for $7 \mathrm{~d}$, until germination, and then for $48 \mathrm{~h}$ in the light. Next, fresh leaves $(300 \mathrm{mg})$ were collected and placed in contact with $10 \mathrm{~mL}$ of $95 \%$ ethanol for $48 \mathrm{~h}$ under light. The absorption of the samples was then measured in a UVVis spectrophotometer at 648 and $664 \mathrm{~nm}$ (33). Chlorophyll $\mathrm{A}$, chlorophyll $\mathrm{B}$, and total chlorophyll were determined by the following equations:

$$
\begin{aligned}
& \text { ChlA }=13.36 A_{664}-5.19 A_{648} . \\
& \text { ChlB }=27.43 A_{648}-8.12 A_{664} \\
& \text { Total chlorophyll }=\text { ChlA }+ \text { ChlB }
\end{aligned}
$$

\section{Ensaios de fitotoxicidade com Cucumis sativus}

\section{Teste de germinação das sementes}

As sementes de Cucumis sativus foram incubadas em placas de Petri contendo um papel filtro qualitativo número 1. Dez sementes, escaladas geometricamente, foram incubadas com $5 \mathrm{~mL}$ de água destilada (controle) ou a respectiva suspensão $\mathrm{CA}$ nas concentrações de 1 , $10,100,1000$ e $10.000 \mathrm{mg} / \mathrm{L}$, durante 7 dias a $25^{\circ} \mathrm{C}$, no escuro. As experiências foram realizadas em triplicado. O número de sementes germinadas foi e o comprimento das raízes foi medido. Sementes germinadas sequencialmente foram incubadas a $60^{\circ} \mathrm{C}$ por $48 \mathrm{~h}$ para determinar os pesos secos.

As mudas foram agrupadas e pesadas em cada réplica e os resultados foram normalizados para o número de sementes germinadas. Para fornecer uma interpretação abrangente, a germinação das sementes e o alongamento das raízes podem ser combinados em um índice de germinação (GI), de acordo com a equação:

$$
G I(\%)=\left(G_{s} L_{s} / G_{c} L_{c}\right) \times 100
$$

onde Gs e Ls são a germinação das sementes (\%) e o alongamento das raízes $(\mathrm{mm})$ para a amostra; Gc e Lc os valores de controle correspondentes (32).

A inibição do alongamento de mudas (SEI\%) fornece informações sobre a inibição (valores positivos) e estimulação (valores negativos) da germinação das sementes. SEI (\%) pode ser calculado pela equação:

$$
\operatorname{SEI}(\%)=\frac{L_{c}-L_{s}}{L_{c}} \times 100
$$

onde Lc e Ls são alongamento da raiz (mm) para o controle e a amostra.

\section{Teor de clorofila}

As sementes de Cucumis sativus foram mantidas em contacto com CA na concentração de $10 \mathrm{~g} / \mathrm{L}$ no escuro por 7 dias, até a germinação e, em seguida, por 48 horas na luz.

Em seguida, folhas frescas (300 mg) foram colectadas e colocadas em contacto com $10 \mathrm{~mL}$ de etanol a $95 \%$ por $48 \mathrm{~h}$ sob luz. A absorção das amostras foi então medida em um espectrofotómetro UV-Vis a 648 e $664 \mathrm{~nm}$. A clorofila A, clorofila B e a clorofila total foram determinadas pelas seguintes equações (33):

$$
\begin{gathered}
\text { ChlA }=13,36 A_{664}-5,19 A_{648} \\
\text { ChlB }=27,43 A_{648}-8,12 A_{664} \\
\text { Clorofila total }=\text { ChlA }+ \text { ChlB }
\end{gathered}
$$




\section{Evaluation of cell death using Evans blue dye}

Loss of cell viability was studied using the Evan's blue staining method. Four root tips with $1 \mathrm{~cm}$ of length from control and treated seeds were stained with $2 \mathrm{~mL}$ of $0.25 \%(\mathrm{w} / \mathrm{v})$ aqueous solution of Evans blue for 15 min, then washed with distilled water. The samples were then incubated for $1 \mathrm{~h}$ at $50{ }^{\circ} \mathrm{C}$ with a sodium lauryl sulfate solution in methanol-water (50:50), and the absorbance was measured at $595 \mathrm{~nm}$ (34).

\section{Hatching the cysts}

The tests were performed according to the protocol developed and validated (35). Dehydrated cysts of Artemia salina were hatched in saline medium (38 $\mathrm{g} / \mathrm{L}$ sea salt) at $\mathrm{pH}$ 8.0. The cysts were dispersed in the medium (100 mg of cysts per $100 \mathrm{~mL}$ of medium) and incubated for $24 \mathrm{~h}$ under light and aeration.

\section{Mortality Rate of Artemia nauplii}

The acute toxicity was determined by measuring the number of dead Artemia. The 24-hour-old nauplii were transferred to 24-well plates, with 10 nauplii placed in contact with the nanomaterial suspensions $(2 \mathrm{~mL})$ at concentrations of $25,50,75,100,125,500,1000$, and $10000 \mathrm{mg} / \mathrm{L}$. Ten replicates were used for each treatment. Saline medium was used as negative control and a solution of $60 \mathrm{mg} / \mathrm{L} \mathrm{K}_{2} \mathrm{Cr}_{2} \mathrm{O}_{7}$ was used as positive control. The plates were incubated in the dark at $24^{\circ} \mathrm{C}$. The number of dead nauplii was evaluated after 24 and 48 $\mathrm{h}$, with immobile nauplii being considered dead. The test was considered valid if less than $10 \%$ of the control nauplii were immobile.

The mortality rate was calculated by following the formula:

$$
\% \text { Mortality }=\frac{\text { Number of dead nauplii }}{\text { Initial number of nauplii }} \times 100
$$

\section{Statistical Analysis}

All experiments were performed in triplicate. Statistical significance was determined by analysis of variance (ANOVA), followed by Dunnett's method and Tukey's test, to determine the statistical significance of each parameter among the treatments, with significant differences at $\mathrm{p}<0.05$, using the software program GraphPad Prism 5 (GraphPad Software, San Diego, CA, USA). All experimental data are presented as mean values \pm standard deviations.
Avaliação da morte celular usando o corante azul de Evans

A perda de viabilidade celular foi estudada usando o método de coloração azul de Evans. Quatro pontas de raiz com $1 \mathrm{~cm}$ de comprimento, das sementes controle e tratadas, foram coradas com $2 \mathrm{~mL}$ de solução aquosa a $0,25 \%(\mathrm{~m} / \mathrm{v})$ de azul de Evans por $15 \mathrm{~min}$ e depois lavadas com água destilada. As amostras foram então incubadas por $1 \mathrm{~h}$ a $50^{\circ} \mathrm{C}$ com uma solução de lauril sulfato de sódio em metanol-água (50:50), e a absorbancia foi medida a $595 \mathrm{~nm}$ (34).

\section{Incubação dos cistos}

Os testes foram realizados de acordo com um protocolo desenvolvido e validado (35). Os cistos desidratados de Artemia salina foram incubados em meio salino (sal marinho $38 \mathrm{~g} / \mathrm{L}$ ) com $\mathrm{pH}$ 8,0. Os cistos foram dispersos no meio (100 mg de cistos por $100 \mathrm{~mL}$ de meio) e incubados durante $24 \mathrm{~h}$ sob luz e injecção de ar comprimido.

\section{Taxa de mortalidade Artemia nauplii}

A toxicidade aguda foi determinada medindo o número de Artemia mortas. Os nauplii com $24 \mathrm{~h}$ de idade foram transferidos para placas de 24 poços, com 10 nauplii colocados em conctato com as suspensões de nanomateriais $(2 \mathrm{~mL})$ nas concentrações de $25,50,75,100$, 125, 500, 1000 e $10000 \mathrm{mg} / \mathrm{L}$. Dez réplicas foram usadas para cada tratamento. $\mathrm{O}$ meio salino foi usado como controle negativo e uma solução de $\mathrm{K}_{2} \mathrm{Cr}_{2} \mathrm{O}_{7}$ a $60 \mathrm{mg} / \mathrm{L}$ foi usada como controle positivo. As placasforam incubadas no escuro a $24{ }^{\circ} \mathrm{C}$. O número de nauplii mortos foi avaliado após 24 e 48 h, sendo considerado nauplii imóvel. O teste foi considerado válido se menos de $10 \%$ dos nauplii controle estivessem imóveis.

A taxa de mortalidade foi calculada seguindo a fórmula:

$$
\% \text { Mortalidade }=\frac{\text { Número de nauplii mortos }}{\text { Número inicial de nauplii }} \times 100
$$

\section{Análises estatísticas}

A significância estatística foi determinada pela análise de variância (ANOVA), seguida pelo método de Dunnett e pelo teste de Tukey, para determinar a significância estatística de cada parâmetro entre os tratamentos, com diferença significativa em $p<0,01$, utilizando o programa GraphPad Prism 5 (GraphPad Software, San Diego, CA, USA). Todos os dados experimentais são apresentados como valores médios \pm desvios padrão 


\section{Results and Discussion}

\section{Preparation of activated carbon}

Among the various types of chemical activation agents, $\mathrm{H}_{2} \mathrm{SO}_{4}$ is frequently used for the preparation of activated carbon from lignocellulose products. The carbonization of termite feces with $\mathrm{H}_{2} \mathrm{SO}_{4}$ resulted in yields ranging from 43.8 to $48.7 \%$, with no direct relationship between the yield and the amount of acid added to the AC. The $\mathrm{H}_{2} \mathrm{SO}_{4}$ causes cleavage of bonds, leading to dehydration and elimination reactions that release volatile products such as water, acetic acid, methanol, and other compounds (36). A similar result was found in the synthesis of AC from flax fibers, where the amounts of $\mathrm{H}_{2} \mathrm{SO}_{4}$ added, from 10 to $18 \mathrm{~mol} / \mathrm{L}$, did not show a significant variation in material yield (37).

Hemicelluloses are readily hydrolysed by dilute acids. Cellulose, because of its high crystallinity and cohesive density, is insoluble in water and more resistant to dilute acids. However, strong acids can cause cellulose to swell, or even dissolve. Concentrated sulfuric acid rapidly dissolves cellulose in the cold, forming a clear solution which, when left to stand, blackens as a result of carbonisation of the cellulose. Lignin is the major component of termite feces, and studies in which sawdust was treated with concentrated $\mathrm{H}_{2} \mathrm{SO}_{4}$ have shown that the polysaccharides are hydrolysed and can be removed, whereas lignin is left as a non-hydrolysed dark/ coloured residue. In short, the preparation of $\mathrm{AC}$ by dehydration of any biomass is a difficult task, as it depends on the type of raw material, the method of treatment, and the intended use of the AC (37).

\section{Characterization of $A C$}

The internal and external surface of the prepared AC was studied using SEM technique. As shown in Figure SI1a, the surface of treated termite feces was homogeneous, smooth, and flat (38). After chemical activation, SEM (Figure SI1), showed the internal pores of the prepared $\mathrm{AC} 12$. The pores and cavities resulted from evaporation of the activating agent $\left(\mathrm{H}_{2} \mathrm{SO}_{4}\right)$ during carbonization, as indicated in literature $(38,39)$.

The characteristics of the activated carbons prepared at $600{ }^{\circ} \mathrm{C}$ using different impregnation ratios of $\mathrm{H}_{2} \mathrm{SO}_{4}$ are shown in Table 1 . The specific surface area (SSA) determined by the amount of adsorbed methylene blue (MB) was calculated by equation [1] (28). Using $\mathrm{H}_{2} \mathrm{SO}_{4}$, as the activating reagent, the maximum surface area was obtained for the activated carbon AC6. Interestingly,

\section{Resultados e Discussão}

\section{Preparação do $C A$}

Entre os vários tipos de agentes químicos de activação, $\mathrm{o}_{2} \mathrm{SO}_{4}$ é frequentemente usado para a preparação de carvão activado a partir de materiais lenho celulósico. A carbonização das fezes de cupim com $\mathrm{H}_{2} \mathrm{SO}_{4}$ resultou em rendimentos variando de 43,8 a $48,7 \%$, sem relação directa entre o rendimento e a quantidade de ácido adicionado ao $\mathrm{CA}$. $\mathrm{O} \mathrm{H}_{2} \mathrm{SO}_{4}$ causa clivagem de ligações, levando a reacções de desidratação e eliminação de produtos voláteis, como água, ácido acético, metanol e outros produtos químicos (36). Resultado semelhante foi encontrado na preparação de CA a partir de fibras de linho, onde as quantidades de $\mathrm{H}_{2} \mathrm{SO}_{4}$ adicionadas, de 10 a $18 \mathrm{~mol} / \mathrm{L}$, não apresentaram variação significativa no rendimento do material (37).

As hemiceluloses são prontamente hidrolisadas por ácidos diluídos. A celulose, devido à sua alta cristalinidade e densidade coesiva é insolúvel em água e mais resistente a ácidos diluídos. No entanto, ácidos fortes podem fazer com que a celulose inche ou até se dissolva. O ácido sulfúrico concentrado dissolve rapidamente a celulose em temperaturas ambiente, formando uma solução clara que, quando deixada em repouso, escurece como resultado da carbonização da celulose. O material lenho celulósico é o principal componente das fezes de cupim, e estudos nos quais a serragem foi tratada com $\mathrm{H}_{2} \mathrm{SO}_{4}$ concentrado mostraram que os polissacarídeos são hidrolisados e podem ser removidos, enquanto a linina é deixada como um resíduo escuro/colorido não hidrolisado. Em suma, a preparação do CA por desidratação de qualquer biomassa é uma tarefa difícil, pois depende do tipo de matéria-prima, do método de tratamento e do uso pretendido do CA (37).

\section{Caracterização do $C A$}

A superfície interna e externa do CA preparado foi estudada pela técnica MEV. Como mostrado na Figura SI1a, a superfície das fezes de cupim tratadas era homogénea, lisa e plana (38). Após activação química, o MEV (Figura SI1) mostrou os poros internos do CA12 preparado. Os poros e cavidades resultaram da evaporação do agente activador $\left(\mathrm{H}_{2} \mathrm{SO}_{4}\right)$ durante a carbonização, como indicado por Hamed, et al., 2016 (39) e Chahm, et al., 2019 (38).

As características dos carvões activos preparados a 600 ${ }^{\circ} \mathrm{C}$ usando diferentes taxas de impregnação de $\mathrm{H}_{2} \mathrm{SO}_{4}$ são mostradas na Tabela 1. A área superficial específica (ASE) determinada pela quantidade de azul de metileno adsorvido (AM) foi calculada pela equação [1] (28). 
when the impregnation ratio increased from 1:6 to 1:1 (termite feces: $\mathrm{H}_{2} \mathrm{SO}_{4}$, the surface area decreased from 303.4 to $162.5 \mathrm{~m}^{2} \mathrm{~g}^{-1}$.

The Boehm titration method provides important infor mation regarding the surface properties of carbon materials. These properties, in turn, may interfere with the performance of the materials in the adsorption processes. The results are shown in Table 1. The results of the titration results revealed that the total acidity of the AC surface increased with the amount of $\mathrm{H}_{2} \mathrm{SO}_{4}$ used in the activation. Functional acid groups have been broadly studied, and the results reported in the literature have demonstrated that $\mathrm{H}_{2} \mathrm{SO}_{4}$ oxidation allows the formation of carboxyl sites. Total acid sites (TAS) of the ACs increased up to $400 \%$ when the amount of $\mathrm{H}_{2} \mathrm{SO}_{4}$ used was increased, mainly reflecting an increase in phenolic groups. However, TAS decreased when a ratio of $1: 1$ $\mathrm{H}_{2} \mathrm{SO}_{4}$ was used for the oxidation of the wood-based activated carbon. These results are similar to those reported in literature, showing that $\mathrm{H}_{2} \mathrm{SO}_{4}$ oxidation increases the total acid groups, mainly due to the formation of carboxylic, phenolic and hydroxyl groups. In addition, the quantity of basic sites increased after chemical oxidation of the activated carbon (40-42).

Table 1 shows the $\mathrm{pH}_{\mathrm{pcz}}$ results of the experiments performed with the $\mathrm{AC}$ 's, where the $\mathrm{pH}$ ranged from 4 to 12 . According to Table 1 , the $\mathrm{pH}_{\mathrm{pcz}}$ decreased with increasing amounts of $\mathrm{H}_{2} \mathrm{SO}_{4}$ used in the activation. Below the $\mathrm{pH}_{\mathrm{pcz}}$ value, the surface of $\mathrm{AC}$ is positively charged due to protonation. Above the $\mathrm{pH}_{\mathrm{pcz}}$, the $\mathrm{AC}$ surface has a negative charge (43).

The iodine number is a measure of micropore content
Utilizando $\mathrm{H}_{2} \mathrm{SO}_{4}$, como reagente de activação, foi obtida a área superficial máxima para o carvão activado CA6. Curiosamente, quando a taxa de impregnação aumentou de 1:6 para 1:1 ( $\left.\mathrm{FC}: \mathrm{H}_{2} \mathrm{SO}_{4}\right)$, a área de superfície diminuiu de 303,4 para $162,5 \mathrm{~m}^{2} \mathrm{~g}^{-1}$.

$\mathrm{O}$ método de titulação de Boehm fornece informações importantes sobre as propriedades da superfície de materiais de carbono. Essas propriedades, por sua vez, podem interferir no desempenho dos materiais nos processos de adsorção. Os resultados são mostrados na Tabela 1. Os resultados da titulação revelaram que a acidez total da superfície do CA aumentou com a quantidade de $\mathrm{H}_{2} \mathrm{SO}_{4}$ usado na activação. Grupos ácidos funcionais têm sido amplamente estudados, e os resultados relatados na literatura demonstraram que a oxidação com $\mathrm{H}_{2} \mathrm{SO}_{4}$ permite a formação de ácidos carboxílicos. Os ácidos orgânicos totais (AOT) dos CAs aumentaram até $400 \%$ quando a quantidade de $\mathrm{H}_{2} \mathrm{SO}_{4}$ usado foi aumentada, recfletindo principalmente um aumento nos grupos fenólicos, Tabela 1. No entanto, o conteúdo de AOT diminuiu quando uma proporção de $1: 1 \mathrm{de}_{2} \mathrm{SO}_{4}$ foi usada para a oxidação do carvão activado à base de madeira. Esses resultados são semelhantes aos relatados na literatura mostrando que a oxidação com $\mathrm{H}_{2} \mathrm{SO}_{4}$ aumenta o total de grupos ácidos, principalmente devido à formação de grupos carboxílico, fenólico e hidroxilo. Além disso, a quantidade de sítios básicos aumentou após a oxidação química do carvão activado (40-42).

A Tabela 1 mostra os resultados de $\mathrm{pH}_{\mathrm{pcz}}$ dos experimentos realizados com os CAs, onde o $\mathrm{pH}$ variou de 4 a 12. De acordo com a Tabela 1, o pHpcz diminuiu com o aumento de quantidades de $\mathrm{H}_{2} \mathrm{SO}_{4}$ usado na ativação.

Table 1 - Characterization parameters of activated carbon

Tabela 1 - Parâmetros de caracterização do carvão ativado

Functional groups / Grupos funcionais

$(\mathrm{mg} / \mathrm{g})$

\begin{tabular}{ccccccccc}
\hline & $\begin{array}{c}\mathrm{I}_{2}{ }^{1} \\
(\mathrm{mg} / \mathrm{g})\end{array}$ & $\begin{array}{c}\mathrm{SSA}^{2} / \\
\mathrm{ASE} \\
\left(\mathrm{m}^{2} / \mathrm{g}\right)\end{array}$ & $\begin{array}{c}\mathrm{pH}_{\mathrm{zc}}{ }^{3} / \\
\mathrm{pH}_{\mathrm{cz}}{ }^{3}\end{array}$ & $\begin{array}{c}\text { Carboxylic } \\
\text { acid groups / } \\
\text { Grupos acido } \\
\text { caboxilicos }\end{array}$ & $\begin{array}{c}\text { Lactone } \\
\text { groups/ } \\
\text { Grupos } \\
\text { lactonas }\end{array}$ & $\begin{array}{c}\text { Phenol groups / } \\
\text { Grupos } \\
\text { fenólicos }\end{array}$ & $\begin{array}{c}\text { Total acid } \\
\text { sites / } \\
\text { Total de } \\
\text { sitios } \\
\text { acidos }\end{array}$ & $\begin{array}{c}\text { Basic sites / } \\
\text { Sitios basicos }\end{array}$ \\
$\mathrm{AC}$ 12 & 171.9 & 303.4 & 9.1 & 9.0 & - & 26.9 & 35.9 & 2.7 \\
$\mathrm{AC} 25$ & 144.5 & 235.4 & 7.5 & 23.4 & 0.4 & 22.9 & 46.7 & 1.3 \\
$\mathrm{AC50}$ & 146.3 & 152.2 & 5.6 & 2.3 & 3.6 & 144.5 & 150.4 & 4.9 \\
\hline
\end{tabular}

${ }^{1}$ Iodine number; ${ }^{2}$ Specific surface area; ${ }^{3} \mathrm{pH}$ point zero charge / ${ }^{1}$ Número de Iodo; ${ }^{2}$ Área supercificial específica; ${ }^{3} \mathrm{pH}$ ponto de carga zero 
and was obtained by the standard method, the measurement of the accessibility of pores with dimensions $\geq 1.0$ $\mathrm{nm}(17,44)$. Table 1 shows the iodine number value of ACs. According to Table 1, the microporosity of the materials had no significant difference in relation to the amount of $\mathrm{H}_{2} \mathrm{SO}_{4}$ used; the iodine number ranged from 146.3 to $173.7 \mathrm{mg} / \mathrm{g}$. The results indicate that AC has a moderate iodine number (45).

The composites containing activated carbon and silver nanoparticles were prepared in one-step. $\mathrm{Ag}^{+}$ions were reduced to $\mathrm{Ag}^{0}$ directly on the $\mathrm{AC}$ surface with an inorganic $\left(\mathrm{NaBH}_{4}\right)$ (46) reducing agent (equation [8]), or an organic reducing agent (sucrose) (47) (quation [9]). A series of composites was prepared without the addition of reducing agents. The chemical reaction involved in the formation of silver nanoparticles by $\mathrm{NaBH}_{4}$ and sucrose are represented by:

$$
\begin{gathered}
\mathrm{AgNO}_{3}+\mathrm{NaBH}_{4} \rightarrow \mathrm{Ag}+1 / 2 \mathrm{H}_{2}+1 / 2 \mathrm{~B}_{2} \mathrm{H}_{6}+\mathrm{NaNO}_{3} \\
\mathrm{CH}_{2} \mathrm{OH}-(\mathrm{CHOH})_{4}-\mathrm{CHO}+2 \mathrm{Ag}^{+}+\mathrm{H}_{2} \mathrm{O} \rightarrow \\
\mathrm{CH}_{2} \mathrm{OH}(\mathrm{CHOH})_{4}-\mathrm{COOH}+2 \mathrm{Ag}+\mathrm{H}^{+}
\end{gathered}
$$

Table 2 shows the amount of silver present in the synthesized ACs. The highest amount of silver was found in the composites prepared using $\mathrm{NaBH}_{4}$ as a reducing agent. The use of sucrose resulted in composites with considerable amounts of silver. On the other hand, composites prepared without reducing agents resulted in a small amount of silver being incorporated into the AC. As shown in Table 2, the amount of acid used in the preparation of the ACs did not influence the amount of silver incorporated into the composite.
Abaixo do valor de $\mathrm{pH}_{\mathrm{pcz}}$, a superfície do CA é carregada positivamente devido à protonação. Acima do $\mathrm{pH}_{\mathrm{pcz}}$, a superfície do CA tem uma carga negative (43).

O número de iodo é uma medida do conteúdo de microporos e foi obtido pelo método padrão para medir a acessibilidade de poros com dimensões $\geq 1.0 \mathrm{~nm}$ $(17,44)$. A Tabela 1 mostra o valor do número de iodo dos CAs. De acordo com a Tabela 1, a microporosidade dos materiais não apresentou diferença significativa em relação à quantidade de $\mathrm{H}_{2} \mathrm{SO}_{4}$ utilizado; o número de iodo variou de 146,3 a $173,7 \mathrm{mg} / \mathrm{g}$. Os resultados indicam que o CA tem um número moderado de iodo (45). Os compósitos contendo carvão activado e nanopartículas de prata foram preparados em uma etapa. $\mathrm{O}$ ião $\mathrm{Ag}^{+}$ foi reduzido para $\mathrm{Ag}^{0}$ directamente na superfície da CA com um agente redutor inorgânico $\left(\mathrm{NaBH}_{4}\right)$ (46) (equação [8]), ou um agente redutor orgânico (sacarose) (47) (equação [9]). A reacção química envolvida na formação de nanopartículas de prata por $\mathrm{NaBH}_{4} \mathrm{e}$ sacarose é representada por:

$$
\begin{array}{cc}
\mathrm{AgNO}_{3}+\mathrm{NaBH}_{4} \rightarrow \mathrm{Ag}+1 / 2 \mathrm{H}_{2}+1 / 2 \mathrm{~B}_{2} \mathrm{H}_{6}+\mathrm{NaNO}_{3} & {[\text { [8] }} \\
\mathrm{CH}_{2} \mathrm{OH}-(\mathrm{CHOH})_{4}-\mathrm{CHO}+2 \mathrm{Ag}^{+}+\mathrm{H}_{2} \mathrm{O} \rightarrow & \text { [9] } \\
\mathrm{CH}_{2} \mathrm{OH}(\mathrm{CHOH})_{4}-\mathrm{COOH}+2 \mathrm{Ag}+\mathrm{H}^{+} &
\end{array}
$$

A Tabela 2 mostra a quantidade de prata presente nos CAs preparados. A maior quantidade de prata foi encontrada nos compósitos preparados usando $\mathrm{NaBH}_{4}$ como agente redutor. $\mathrm{O}$ uso de sacarose resultou em compósitos com quantidades consideráveis de prata. Por outro lado, os compósitos preparados sem agentes redutores resultaram na incorporação de uma pequena quantidade de prata no CA. Como mostrado na Tabela 2, a quantidade de ácido usada na preparação dos CAs não influenciou a quantidade de prata incorporada no compósito.

Table 2 - Silver amount incorporated into the AC

Tabela 2 - Quantidade de prata nos compósitos

\begin{tabular}{cc}
\hline Composite / Composito & $\begin{array}{c}\text { Silver load / } \\
\text { quantidade de prata } \\
(\mathrm{mg} / \mathrm{g})\end{array}$ \\
\hline AC6Ag & 23.4 \\
AC12Ag & 19.5 \\
AC25Ag & 11.7 \\
AC50Ag & 58.6 \\
AC6AgB & 133.7 \\
AC12AgB & 109.3 \\
AC25AgB & 156.2 \\
AC50AgB & 136.6 \\
AC6AgS & 46.9 \\
AC12AgS & 50.8 \\
AC25AgS & 31.2 \\
AC50AgS & 35.7 \\
\hline
\end{tabular}


Antimicrobial activity of the composites

\section{Minimal inhibitory concentration (MIC)}

The MIC is defined as the lowest concentration of a drug that will inhibit the visible growth of microorganism after a period long ( $24 \mathrm{~h}$ ), the growth of colony to a turbid bacteria culture observable to the naked eye. The MIC of the compounds to E. coli, S. aureus and $C$. albicans were determined using the double dilution method. The representative growth status of microbial strains in the presence of varying concentrations of disinfectants is shown in Table 3.

The results of the silver MIC were calculated in proportion to the amount of silver present in the composite (Table 2). The ACs without silver (AC6-AC50) did not present antibacterial or antifungal activity against the tested microorganisms

Table 3 shows that the AC25Ag and AC12Ag composites prepared without reducing agents had the same MIC $(500 \mu \mathrm{g} / \mathrm{mL})$ for both $S$. aureus and E. coli. The AC25AgB composite prepared with $\mathrm{NaBH}_{4}$ as reducing agent had a MIC of $(500 \mu \mathrm{g} / \mathrm{mL})$ for $S$. aureus, the composites $\mathrm{AC} 12 \mathrm{AgB}, \mathrm{AC} 25 \mathrm{AgB}$, and $\mathrm{AC} 50 \mathrm{AgB}$ had a MIC of $(500 \mu \mathrm{g} / \mathrm{mL})$ for E. coli. The AC12AgS composite prepared using sucrose, had a MIC of $(500 \mu \mathrm{g} /$ $\mathrm{mL}$ ) for both E. coli and C. albicans, and AC6AgS had a MIC of $(500 \mu \mathrm{g} / \mathrm{mL})$ for $S$. aureus. The MIC values found are well below those reported in the literature for silver nanoparticle-impregnated carbonaceous materials: graphene oxide $/ \mathrm{Ag}^{0} \mathrm{MIC} 2000 \mu \mathrm{g} / \mathrm{mL}$ for $S$. aureus and E. coli (48); commercial activated carbon MIC 600 $\mu \mathrm{g} / \mathrm{mL}$ and $1250 \mu \mathrm{g} / \mathrm{mL}$ for $E$. coli and $S$. aureusrespectively (18).

The efficiency of nanomaterials is even more evident when we compare the MIC values based on the concentration of Ag. It was observed that the amount present in the ACAg compounds prepared without reducing agent $(6-58 \mu \mathrm{g} / \mathrm{mL})$ is lower than those found in the compounds prepared with $\mathrm{NaBH}_{4}(78-136 \mu \mathrm{g} / \mathrm{mL})$. One of the hypotheses for these results is the presence of $\mathrm{Ag}^{+}$ions in the composite prepared without reducing agent. Higher toxicity against bacteria has been reported for the $\mathrm{Ag}^{+}$ion compared to $\mathrm{Ag}^{0}$ (49). The decrease in antimicrobial activity with the increase of silver may be related to the increase in nanoparticle size, decreasing the potential for the release of silver ions and leading to a reduction in the antibacterial activities of the materials (50-51).

The MICs of $8.5 \mu \mathrm{g} / \mathrm{mL}$ and $6.0 \mu \mathrm{g} / \mathrm{mL}$ found for both E. coli and S. aureus for AC12Ag and AC25Ag, respectively, were very close to that reported for commercial activated carbon (10 and $5 \mu \mathrm{g} / \mathrm{mL}$ ) (52). The MIC for
Atividade antimicrobiana dos compósitos

\section{Concentração inibitória mínima (CIM)}

A CIM é definida como a menor concentração de um medicamento que inibirá o crescimento visível do microrganismo após $24 \mathrm{~h}$, o crescimento da colonia em uma cultura de bactérias turva é observável a olho nu. A CIM dos compostos para E. coli, S. aureus e C. albicans foi determinada usando o método de dupla diluição. O status de crescimento representativo das cepas microbianas na presença de concentrações variadas de desinfectantes é mostrado na Tabela 3.

Os resultados da CIM de prata foram calculados proporcionalmente à quantidade de prata presente no compósito (Tabela 2). Os CAs sem prata (CA6-CA50) não apresentaram actividade antibacteriana ou antifúngica contra os microrganismos testados.

A Tabela 3 mostra que os compósitos CA25Ag e CA12Ag preparados sem agentes redutores tinham a mesma CIM $500 \mu \mathrm{g} / \mathrm{mL}$ para $S$. aureus e E. coli. O compósito preparado com $\mathrm{NaBH}_{4}$ como agente redutor CA25AgB apresentou CIM $500 \mu \mathrm{g} / \mathrm{mL}$ para $S$. aureus, os compósitos CA12AgB, CA25AgB e CA50AgB apresentaram CIM $500 \mu \mathrm{g} / \mathrm{mL}$ para E. coli. O compósito preparado com sacarose, CA12AgS, teve uma CIM de $500 \mu \mathrm{g} / \mathrm{mL}$ para E. coli e C. albicans, e CA6AgS teve uma CIM de $500 \mu \mathrm{g} / \mathrm{mL}$ para $S$. aureus. Os valores de CIM encontrados estão bem abaixo dos relatados na literatura para materiais carbonáceos impregnados com nanopartículas de prata:óxido de grafeno $/ \mathrm{Ag}^{0} \mathrm{CIM}$ $2000 \mu \mathrm{g} / \mathrm{mL}$ para $S$. aureus e E. coli (48); carvão activado comercial CIM $600 \mu \mathrm{g} / \mathrm{mL}$ e $1250 \mu \mathrm{g} / \mathrm{mL}$ para $E$. coli e $S$. aureus respectivamente (18).

A eficiência dos nanomateriais é ainda mais evidente quando comparamos os valores de CIM com base na concentração de Ag. Observa-se que a quantidade presente nos compostos preparados sem o agente redutor CAAg (6-58 $\mu \mathrm{g} / \mathrm{mL})$ é menor que a encontrada nos compostos preparados com $\mathrm{NaBH}_{4}(78-136 \mu \mathrm{g} / \mathrm{mL})$. Uma das hipóteses para esses resultados é a presença de ião $\mathrm{Ag}^{+}$no compósito preparado sem agente redutor. A literatura relata que o ião $\mathrm{Ag}^{+}$apresenta maior toxicidade contra bactérias que ${\mathrm{o} \mathrm{Ag}^{0}}$ (49). A diminuição da atividade antimicrobiana com o aumento da prata pode estar relacionada ao aumento do tamanho das nanopartículas, o que diminuiu o potencial de liberação de iões $\mathrm{Ag}^{+}$, levando a uma redução nas actividades antibacterianas dos materiais $(50,51)$.

As CIMs de $8,5 \mu \mathrm{g} / \mathrm{mL}$ e $6,0 \mu \mathrm{g} / \mathrm{mL}$ encontradas para E. coli e $S$. aureus para CA12Ag e CA25Ag, respectivamente, foram muito próximo do relatado para carvão activado comercial (10 e $5 \mu \mathrm{g} / \mathrm{mL})$ (52). A CIM de $E$. 
Table 3 - Minimal inhibitory concentration (MIC) of silver composites on S. aureus, E. coli, and C. albicans

Tabela 3 - Concentração Inibitória Mínima (CIM) de prata nos compósito sobre o $S$. aureus, E. coli, e C. albicans

\begin{tabular}{ccccccc}
\hline \multicolumn{7}{c}{ MIC / CIM $(\mu \mathrm{g} / \mathrm{mL})$} \\
\hline S. aureus & \multicolumn{2}{c}{ E. coli } & \multicolumn{2}{c}{ C. albicans } \\
\hline Composite / Compósito & Total & $\mathrm{Ag}$ & Total & $\mathrm{Ag}$ & Total & $\mathrm{Ag}$ \\
\hline AC6Ag & 1000 & 23 & 1000 & 23 & $>1000$ & $>23$ \\
AC12Ag & 500 & 8.5 & 500 & 8.5 & $>1000$ & $>19$ \\
AC25Ag & 500 & 6 & 500 & 6 & $>1000$ & $>11$ \\
AC50Ag & 1000 & 58 & 1000 & 58 & $>1000$ & $>58$ \\
AC6AgB & 1000 & 133 & 1000 & 133 & $>1000$ & $>133$ \\
AC12AgB & 1000 & 109 & 500 & 54 & $>1000$ & $>109$ \\
AC25AgB & 500 & 78 & 500 & 78 & $>1000$ & $>156$ \\
AC50AgB & 1000 & 136 & 500 & 68 & $>1000$ & $>136$ \\
AC6AgS & 1000 & 46 & 500 & 23 & 500 & 23 \\
AC12AgS & 2000 & 100 & 1000 & 50 & $>1000$ & $>50$ \\
AC25AgS & 2000 & 71 & 1000 & 31 & $>1000$ & $>36$ \\
AC50AgS & 2000 & 75 & 1000 & 50 & $>1000$ & $>38$ \\
\hline
\end{tabular}

E. coli with AC12Ag and AC25Ag was approximately half of that found for activated carbon obtained from coconut shell, $16 \mu \mathrm{g} / \mathrm{mL}$ (53). However, it was well above the results found for activated carbon prepared with bamboo, which had MIC values $>3.0 \mu \mathrm{g} / \mathrm{mL}$ against both E. coli and $S$. aureus (54).

\section{Growth curves of the microorganism}

Growth inhibition effects of the composites AC25AgB and $\mathrm{AC} 6 \mathrm{AgB}$ were demonstrated with the microorganism growth curves. The bacterial growth was monitored by measuring the optical density at $600 \mathrm{~nm}$ (OD600) based on the turbidity of the cell suspension. As shown in Figure 1A, the lag phase of E. coli is less than $4 \mathrm{~h}$ for the control group. However, incubation with AC25AgB significantly prolonged the lag phase to $24 \mathrm{~h}$, at dose of $250 \mathrm{mg} / \mathrm{L}$ and over $30 \mathrm{~h}$ for doses of 500, 750, and 1000 $\mathrm{mg} / \mathrm{L}$. For $S$. aureus, the lag phase was extended from 1 to 4 hours at a dose of $250 \mathrm{mg} / \mathrm{L}$ and over $48 \mathrm{~h}$ for doses of 500, 750, and $1000 \mathrm{mg} / \mathrm{L}$ (Figure 1B). It appears that the $\mathrm{AC} 25 \mathrm{AgB}$ had a greater effect on Gram-positive than Gram-negative bacteria. The lag phase of C. albicans was less than $4 \mathrm{~h}$ for the control group, but was extended to $24 \mathrm{~h}$ when exposed to $500 \mathrm{mg} / \mathrm{L} \mathrm{AC6AgB}$ composite. At doses of 1000, 1500 and $2000 \mathrm{mg} / \mathrm{g}$ the lag phase was extended to $48 \mathrm{~h}$, Figure 1C. These results are in agreement with those presented in the MIC determination, which showed antimicrobial activity at the same concentrations. Growth inhibition effects of coli, encontrada no CA12Ag e no CA25Ag, foi aproximadamente metade da encontrada para o carvão activado obtido da casca de coco, $16 \mu \mathrm{g} / \mathrm{mL}$ (53). No entanto, ficou bem acima dos resultados encontrados para o carvão activado preparado com bambu, que apresentou CIM $>3,0 \mu \mathrm{g} / \mathrm{mL}$ para E. coli e $S$. aureus (54).

\section{Curva de crescimento dos micro-organismos}

Os efeitos de inibição do crescimento dos compósitos $\mathrm{CA} 25 \mathrm{AgB}$ e $\mathrm{CA} 6 \mathrm{AgB}$ foram demonstrados com as curvas de crescimento de microrganismos. O crescimento bacteriano foi monitorado medindo a densidade óptica a $600 \mathrm{~nm}$ (DO600) com base na turbidez da suspensão celular. Como mostrado na Figura 1A, a fase de atraso de $E$. coli é inferior a $4 \mathrm{~h}$ para o grupo controle. No entanto, a incubação com CA25AgB prolongou significativamente a fase de atraso para $24 \mathrm{~h}$, na dose de 250 $\mathrm{mg} / \mathrm{L}$ e mais de $30 \mathrm{~h}$ para doses de 500, 750 e 1000 $\mathrm{mg} / \mathrm{L}$. Para $S$. aureus, a fase de retardo foi estendida de $1 \mathrm{a} 4$ horas na dose de $250 \mathrm{mg} / \mathrm{L}$ e mais de $48 \mathrm{~h}$ para doses de 500, 750 e $1000 \mathrm{mg} / \mathrm{L}$ (Figura 1B). Parece que o CA25AgB tem um efeito maior nas bactérias Grampositivas do que nas Gram-negativas. A fase de atraso de $C$. albicans foi inferior a $4 \mathrm{~h}$ para o grupo controle, mas foi estendida para $24 \mathrm{~h}$ quando exposta a $500 \mathrm{mg} / \mathrm{L}$ de composto CA6AgB. Nas doses de 1000, 1500 e 2000 $\mathrm{mg} / \mathrm{g}$, a fase de atraso foi estendida para $48 \mathrm{~h}$, Figura 1C. Esses resultados estão de acordo com os apresentados na determinação da CIM, que mostrou actividade 
(a)

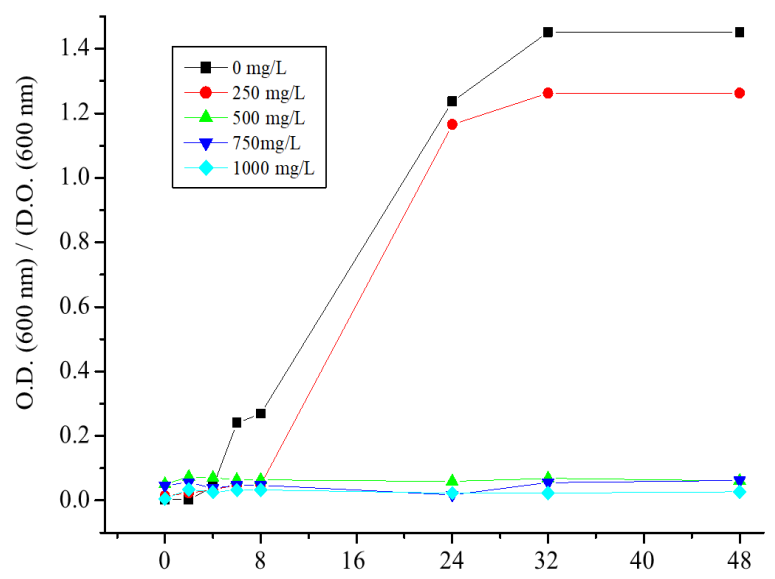

(b)

Time (h) / Tempo (h)

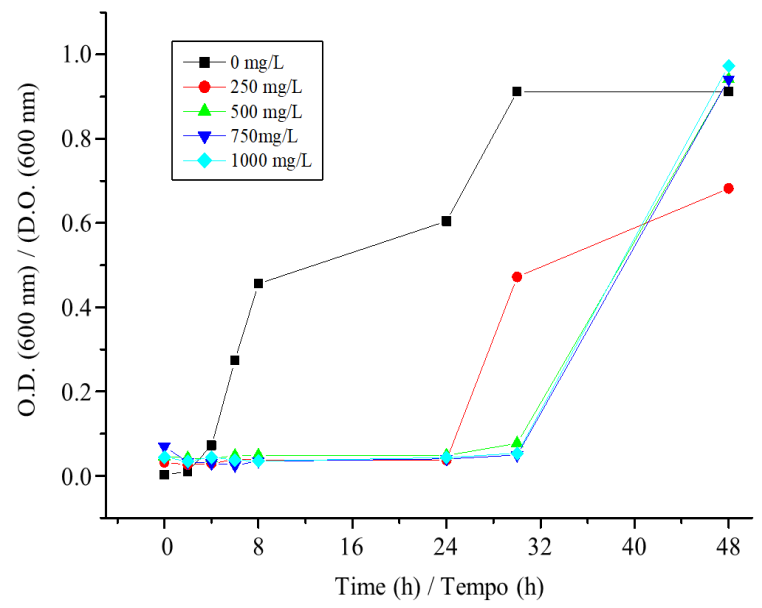

(c)

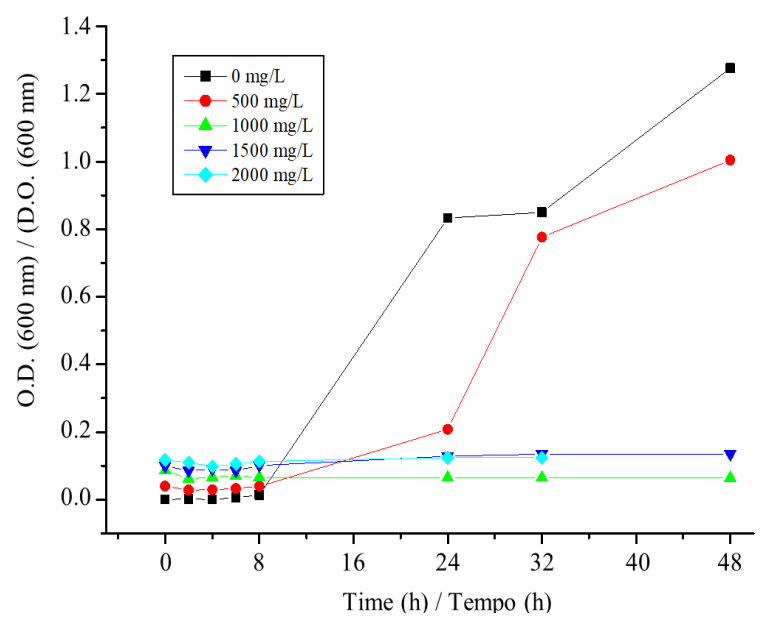

Figure 1 - Growth curves of E. coli exposure to AC25AgB composite (a); S. aureus exposure (b) and $C$. albicans (c) exposure to AC6AgB composites. Control represents bacterial culture without any Ag formulations (black). Bacterial growth is measured as the optical density at $600 \mathrm{~nm}$. Incubation time $=0 \mathrm{~h}$ corresponds to the time at which the composite is added to the bacterial broth.

Figura 1 - Curva de crescimento do E. coli exposto ao compósito CA25AgB (a); S. aureus (b) e C. albicans (c) exposta ao compósito CA6AgB. Controle representa a cultura das bactérias sem prata (preto). Crescimento bacteriano é medido através da densidade ótica em $600 \mathrm{~nm}$. Tempo de incubação $=0 \quad \mathrm{~h}$ corresponde ao tempo em que os compósitos foram adicionados no caldo bacteriano 
the other composites are shown in the supplementary information (SI4). Similar results were found for rice husk-based carbon with silver nanoparticles at the composite contact time with the $18 \mathrm{~h}$ for $E$. coli (55).

In another study of antibacterial activity with silver nanoparticle-loaded carbon nanospheres, the growth of $E$. coli was completely inhibited at a concentration greater than $50 \mathrm{mg} / \mathrm{L}$ (56).

\section{Phytotoxicity}

\section{Seedling Elongation Inhibition (SEI)}

The effect of composites on Cucumis sativus growth was evaluated by seed germination in contact with suspensions containing increasing concentrations of the materials. Root length measurements were used to calculate the value (SEI \%). Positive values represent growth inhibition, and negative values represent growth stimulation.

The effect of composite on seedling growth was calculated by SEI are shown in Figure S3 and Figure 2. The antimicrobiana nas mesmas concentrações. Os efeitos de inibição do crescimento dos outros compósitos são mostrados nas informações suplementares (SI4). Resultados semelhantes foram encontrados para carbono à base de casca de arroz com nanopartículas de prata no tempo de conctato composto com 18 h para $E$. coli (55). Em outro estudo da actividade antibacteriana com nanoesferas de carbono carregadas com nanopartículas de prata, o crescimento de $E$. coli foi totalmente inibido em uma concentração superior a 50 mg/L (56).

\section{Fitotoxicidade}

\section{Inibição do alongamento das plantulas (IAP)}

O efeito dos compósitos no crescimento de Cucumis sativus foi avaliado por germinação de sementes em conctato com suspensões contendo concentrações crescentes dos materiais. As medidas do comprimento da raiz foram usadas para calcular o valor IAP (\%). Valores positivos representam inibição do crescimento e valores negativos representam estimulação do crescimento.

O efeito do compósito no crescimento de plântulas cal-
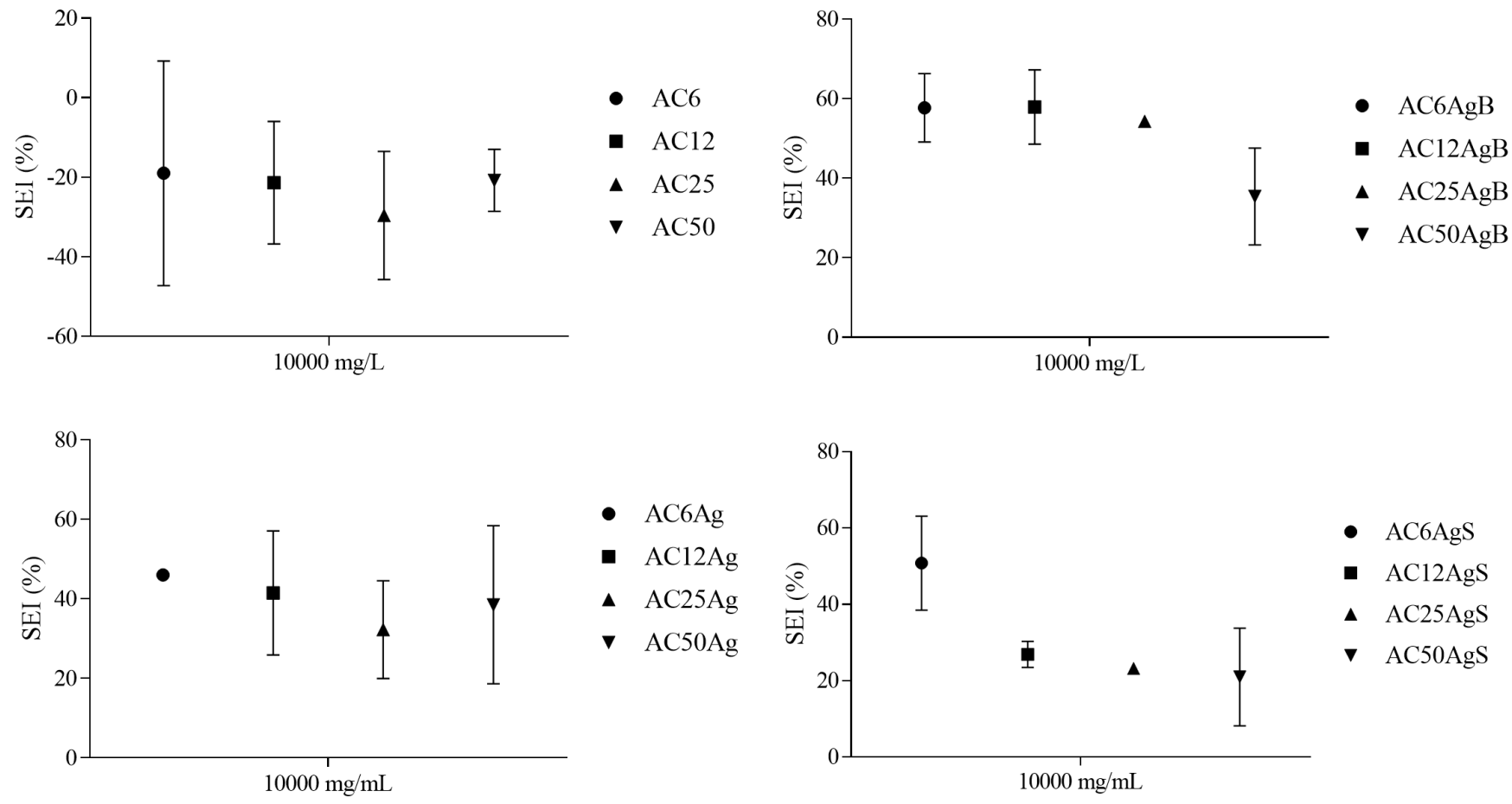

Figure 2 - Influence of composites on seedling elongation Inhibition (SEI). Values are means of three replicates \pm SD. Different letters indicate significant differences (ANOVA followed by Tukey's test, $p<0.05$ ), at concentration of $10,000 \mathrm{mg} / \mathrm{L}$.

Figura 2 - Influência dos compositos sobre a inibição do alongamento da plantula (IAP). Os valores representam a média de três réplicas \pm DP. Diferentes letras indicam diferenças significativas (teste ANOVA seguido de teste Tukey’s , p <0,05), na concentração de $10.000 \mathrm{mg} / \mathrm{L}$. 
AC had a growth stimulation effect, with no relationship between the concentration of $\mathrm{H}_{2} \mathrm{SO}_{4}$ used in the activation of termite feces and SEI, and higher stimulation at the concentration of $10,000 \mathrm{mg} / \mathrm{L}(29.6 \pm 16.1 \%)$ for $\mathrm{AC} 25$.

The composites containing silver nanoparticles (prepared using $\mathrm{NaBH}_{4}$ ) showed inhibition at all concentrations $(10-1000 \mathrm{mg} / \mathrm{mL})$, without a dose-dependent effect and without significant differences $(\mathrm{p}<0.05)$ between them for composites (Figure S3).

Composites prepared with the lowest amount of $\mathrm{H}_{2} \mathrm{SO}_{4}$ (AC6Ag, AC2AgB and AC6AgS) at the dose of 10,000 $\mathrm{mg} / \mathrm{g}$ showed the highest inhibitory effect on SEI, with inhibition of around $60 \%$. This demonstrates that the silver-impregnated active carbons showed toxicity to C. sativus in the elongation stage. Similar results were observed for root growth of cucumber seeds when using Ag-NP (57). The same behavior has also been reported for the use of Ag-NP and $\mathrm{AgNO}_{3}$, resulting in a severe reduction in growth parameters of C. sativus (58).

\section{Germination index (GI)}

The GI can assume values greater or lower than $100 \%$, where a value equal to $100 \%$ indicates that the average seedling length and germination rate between a specific treatment and negative control are the same. With values of between $80 \%$ and $120 \%$, the effects are similar to those produced by the negative controls, while values greater than $120 \%$ indicate biostimulation, and values lower than $80 \%$ indicate inhibition (7).

The results of GI are presented in Figure 3. The active carbon without silver presented a general stimulation tendency, at the concentration of $10000 \mathrm{mg} / \mathrm{L}$, for an effect greater than $120 \%(130 \pm 2.5 \%)$ for $\mathrm{AC} 25$, without significant difference $(\mathrm{p}>0.05)$. The activated carbons prepared using $\mathrm{NaBH}_{4}$ showed a negative effect on germination and growth, with values ranging from 35-60 $\%$, depending on the amount of acid used for the preparation. On the other hand, there was no correlation with the amount of silver contained in the composites. This effect was only observed at the concentration of 10000 $\mathrm{mg} / \mathrm{L}$ (Figure S2). The composites containing silver nanoparticles, prepared with reducing agent or sucrose, also had negative effects, with GI $<80 \%$ for all composites. The GI results showed the same tendency, as shown by the SEI, with low GI values being attributed to inhibition of root growth. Similar results were previously found using Ag-NP in C. sativus germination, where a significant decrease in GI was observed (57). culado por IAP são mostrados na Figura S3 e Figura 2. O CA teve um efeito de estimulação do crescimento, sem relação entre a concentração de $\mathrm{H}_{2} \mathrm{SO}_{4}$ usado na activação das fezes de cupins e IAP, e maior estímulo na concentração de $10 \mathrm{~g} / \mathrm{L}(29,6 \pm 16,1 \%)$ para o CA25. Os compósitos contendo nanopartículas de prata (preparadas com $\mathrm{NaBH}_{4}$ ) apresentaram inibição em todas as concentrações $(10-1000 \mathrm{mg} / \mathrm{mL})$, sem efeito dosedependente e sem diferenças significativas $(\mathrm{p}<0,05)$ entre eles para compósitos (Figura S3).

Os compósitos preparados com a menor quantidade de $\mathrm{H}_{2} \mathrm{SO}_{4}(\mathrm{CA} 6 \mathrm{Ag}, \mathrm{CA} 2 \mathrm{AgB}$ e CA6AgS) na dose de $10.000 \mathrm{mg} / \mathrm{g}$ apresentaram o maior efeito inibitório no IAP, com inibição em torno de $60 \%$. Isso demonstra que os carvões activados impregnados com prata apresentaram toxicidade para $C$. sativus no estágio de alongamento. Resultados semelhantes foram observados para o crescimento radicular de sementes de pepino ao usar NP-Ag (57). O mesmo comportamento também foi relatado para o uso de $\mathrm{NP}-\mathrm{Ag}$ e $\mathrm{AgNO}_{3}$, resultando em uma redução severa nos parâmetros de crescimento de C. sativus (58).

\section{Índice de germinação (IG)}

O IG pode assumir valores maiores ou menores que $100 \%$, o valor igual a $100 \%$ significa que o comprimento médio das plântulas e a taxa de germinação entre um tratamento específico e o controle negativo são os mesmos. Com valores entre $80 \%$ e $120 \%$, os efeitos são semelhantes aos produzidos pelos controles negativos, enquanto valores superiores a $120 \%$ indicam bioestimulação e valores inferiores a $80 \%$ indicam inibição (7). Os resultados do IG são apresentados na Figura 3. O CA sem prata apresentou uma tendência geral de estimulação, na concentração de $10000 \mathrm{mg} / \mathrm{L}$, para um efeito superior a $120 \%(130 \pm 2,5 \%)$ para CA25, sem diferença significativa $(\mathrm{p}>0,05)$. Os CAs preparados com $\mathrm{NaBH}_{4}$ apresentaram efeito negativo na germinação e crescimento, com valores variando de 35 a $60 \%$, dependendo da quantidade de ácido utilizado na preparação. Por outro lado, não houve correlação com a quantidade de prata contida nos compósitos. Este efeito foi observado apenas na concentração de $10000 \mathrm{mg} / \mathrm{L}$ (Figura S2). Os compósitos contendo nanopartículas de prata, preparados com redutor ou sacarose, também tiveram efeitos negativos, com IG $<80 \%$ para todos os compósitos. Os resultados do IG mostraram a mesma tendência, como demonstrado pelo SEI, com baixos valores de IG atribuídos à inibição do crescimento radicular. Resultados semelhantes foram encontrados anteriormente usando NPs-Ag na germinação de $C$. sativus, houve uma diminuição significativa no IG (57). 

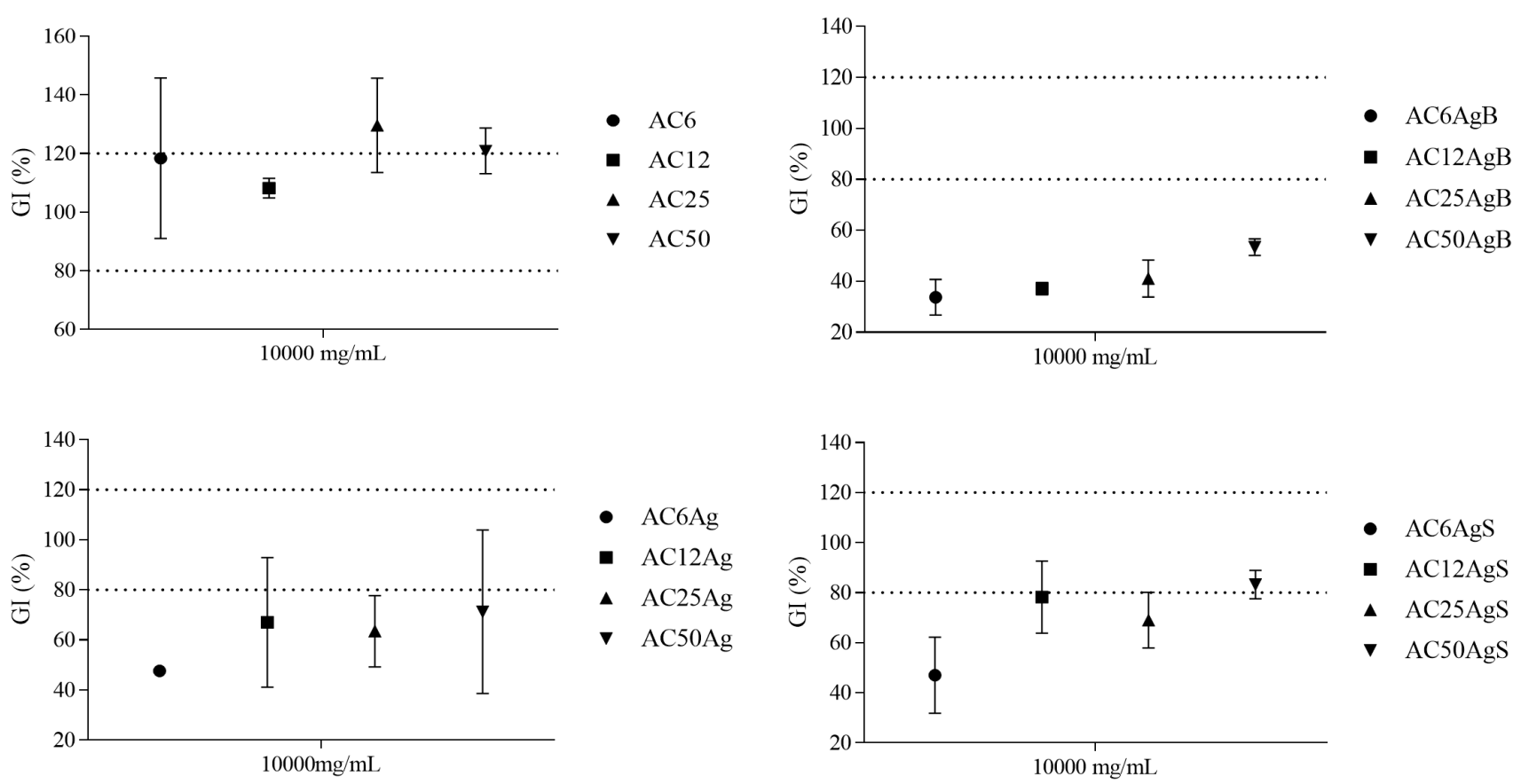

Figure 3 - Influence of composites on germination index (GI). Values are means of three replicates \pm SD. No statistically significant differences were detected at concentration of $10,000 \mathrm{mg} / \mathrm{L}$, see text.

Figura 3 - Influência dos compósitos sobre o indice de germinação (IG). Os valores representam a média de três réplicas \pm DP. Não foram detectadas diferenças estatisticamente significativas na concentração de 10.000 $\mathrm{mg} / \mathrm{L}$, ver texto.

\section{Dry weight}

The impact of the composites on the dry weight of $\mathrm{C}$. sativuu was measured. The results are shown Table 4. Seedling dry weight after 7 days of incubation with composites was normalized according to the number of germinated seeds of $C$. sativus. According to Table 5, no significant difference $(\mathrm{p}>0.05)$ was found between treatments and between treatment and negative control for all composites at a concentration of $10 \mathrm{~g} / \mathrm{L}$. The results differ from those reported or $C$. sativus treated with Ag-NP and $\mathrm{AgNO}_{3}$, in which there was a significant reduction in dry weight (58).

\section{Chlorophyll content}

Chlorophyll A (Chl A) and chlorophyll B (Chl B) play a fundamental role in photosynthesis: they both absorb at the same wavelength range that is necessary to transform light energy into chemical energy. Because chlorophyll is extremely important for the metabolic process, a decrease in the chlorophyll content can be problematic for the plant. Table 4 shows the effects of composites addition to C. sativus on the ChlA and

\section{Peso seco}

Foi medido o impacto dos compósitos no peso seco de C. sativus. Os resultados são mostrados na Tabela 4. O peso seco das plântulas após 7 dias de incubação com compósitos foi normalizado de acordo com o número de sementes germinadas de C. sativus. De acordo com a Tabela 5, não foi encontrada diferença significativa $(p>0,05)$ entre os tratamentos e entre o tratamento e o controle negativo para todos os compósitos na concentração de $10 \mathrm{~g} / \mathrm{L}$. Os resultados são diferentes daqueles relatados com C. sativus tratadas com NP-Ag e $\mathrm{AgNO}_{3}$, nos quais houve uma redução significativa no peso seco (58).

\section{Teor de clorofila}

A clorofila A (ClA) e a clorofila B (ClB) desempenham um papel fundamental na fotossíntese: ambas absorvem nas mesmas faixas do espectro do espectro de ultravioleta necessária para transformar a energia luminosa em energia química. Como a clorofila é extremamente importante para o processo metabólico, uma diminuição no teor de clorofila pode ser problemática para a planta. A Tabela 4 mostra os efeitos da adição de compósitos 
Table 4 - Phytotoxicity parameters on $C$. sativus seedlings. ${ }^{*} \mathrm{p}<0.05$

Tabela 4 - Parâmetros de fitotoxicidade sobre as mudas de C. sativus. ${ }^{*} \mathrm{p}<0.05$

\begin{tabular}{|c|c|c|c|c|}
\hline & $\begin{array}{c}\text { Chlorophyll A / } \\
\text { Clorofila A } \\
(\mathrm{mg} / \mathrm{g})\end{array}$ & $\begin{array}{c}\text { Chlorophyll B / } \\
\text { Clorofila B } \\
(\mathrm{mg} / \mathrm{g})\end{array}$ & $\begin{array}{c}\text { Evans blue } \\
\text { Azul de Evans } \\
\text { (O.D. / D.O. } 595 \mathrm{~nm} \text { ) }\end{array}$ & $\begin{array}{c}\text { Dry weight / } \\
\text { Peso seco } \\
(\mathrm{mg})\end{array}$ \\
\hline \multicolumn{5}{|c|}{ Activated carbon / Carvão ativado } \\
\hline $\begin{array}{l}\text { Control / } \\
\text { controle }\end{array}$ & $14.9 \pm 4.4$ & $6.7 \pm 2.7$ & $0.44 \pm 0.12$ & $117 \pm 30$ \\
\hline AC6 & $13.8 \pm 5.3$ & $6.5 \pm 2.4$ & $0.42 \pm 0.13$ & $147 \pm 10$ \\
\hline $\mathrm{AC} 12$ & $12.1 \pm 4.4$ & $6.4 \pm 2.2$ & $0.43 \pm 0.23$ & $151 \pm 2$ \\
\hline $\mathrm{AC} 25$ & $11.4 \pm 5.1$ & $7.3 \pm 2.9$ & $0.43 \pm 0.22$ & $152 \pm 9$ \\
\hline $\mathrm{AC} 50$ & $14.8 \pm 1.6$ & $6.4 \pm 1.3$ & $0.42 \pm 0.20$ & $161 \pm 2$ \\
\hline $\begin{array}{l}\text { Control / } \\
\text { controle }\end{array}$ & $15.9 \pm 3.0$ & $7.2 \pm 1.4$ & $0.56 \pm 0.05$ & $142 \pm 19$ \\
\hline AC6Ag & $12.5 \pm 1.9$ & $6.4 \pm 0.8$ & $0.44 \pm 0.01$ & $123 \pm 16$ \\
\hline $\mathrm{AC} 12 \mathrm{Ag}$ & $15.6 \pm 0.2$ & $7.2 \pm 0.4$ & $0.38 \pm 0.11$ & $146 \pm 2$ \\
\hline $\mathrm{AC} 25 \mathrm{Ag}$ & $13.4 \pm 0.2$ & $6.0 \pm 0.8$ & $0.35 \pm 0.10$ & $148 \pm 3$ \\
\hline $\mathrm{AC} 50 \mathrm{Ag}$ & $14.6 \pm 1.6$ & $7.0 \pm 1.4$ & $0.32 \pm 0.01$ & $140 \pm 5$ \\
\hline $\begin{array}{l}\text { Control / } \\
\text { controle }\end{array}$ & $16.5 \pm 2.1$ & $8.0 \pm 0.8$ & $0.40 \pm 0.15$ & $131 \pm 8$ \\
\hline $\mathrm{AC} 6 \mathrm{AgB}$ & $8.0 \pm 3.2 *$ & $4.7 \pm 1.6$ & $0.47 \pm 0.29$ & $151 \pm 5$ \\
\hline $\mathrm{AC} 12 \mathrm{AgB}$ & $9.2 \pm 1.2 *$ & $4.7 \pm 1.1$ & $0.41 \pm 0.16$ & $135 \pm 18$ \\
\hline $\mathrm{AC} 25 \mathrm{AgB}$ & $11.8 \pm 2.4$ & $5.3 \pm 1.1$ & $0.45 \pm 0.22$ & $135 \pm 27$ \\
\hline $\mathrm{AC} 50 \mathrm{AgB}$ & $9.9 \pm 4.0$ & $5.5 \pm 0.7$ & $0.35 \pm 0.12$ & $152 \pm 13$ \\
\hline $\begin{array}{l}\text { Control / } \\
\text { controle }\end{array}$ & $15.9 \pm 3.0$ & $7.4 \pm 1.7$ & $0.56 \pm 0.05$ & $138 \pm 17$ \\
\hline $\mathrm{AC} 6 \mathrm{AgS}$ & $11.8 \pm 1.6$ & $5.8 \pm 0.9$ & $0.47 \pm 0.01$ & $147 \pm 2$ \\
\hline $\mathrm{AC} 12 \mathrm{AgS}$ & $11.0 \pm 2.0^{*}$ & $5.4 \pm 0.6$ & $0.50 \pm 0.18$ & $136 \pm 14$ \\
\hline $\mathrm{AC} 25 \mathrm{AgS}$ & $12.4 \pm 1.6$ & $5.7 \pm 0.1$ & $0.40 \pm 0.12$ & $131 \pm 15$ \\
\hline $\mathrm{AC} 50 \mathrm{AgS}$ & $13.6 \pm 2.3$ & $6.7 \pm 0.2$ & $0.45 \pm 0.18$ & $133 \pm 17$ \\
\hline
\end{tabular}

ChlB contents. The ChlA content of $C$. sativus exposed to suspensions of the composite at a concentration of $10 \mathrm{~g} / \mathrm{L}$ showed a reduction with significant difference ( $\mathrm{p}<0.05$ ) for AC6AgB (52\% reduction), AC12AgB (44\% reduction) and $\mathrm{AC} 12 \mathrm{AgS}$ (31\% reduction) when compared to the control. Similar results were found for Crambe abyssinica (59), Oryza sativa L. (60) with inhibition of ChlB synthesis, and Lycopersicon esculentum (61) with inhibition of both ChlA and ChlB synthesis, and Physalis peruviana L. total chlorophyll (62) when exposed to silver nanoparticles. Chlorophyll content, which acts as a biomarker of the photosynthetic activity of a plant, may be reduced when exposed to metals. Decreased chlorophyll contents indicate disturbed chlorophyll synthesis which may have serious implications on the synthesis of organic food material (63). The decrease in chlorophyll contents in tissues of metaltreated plants is dependent on several factors, such as a disturbance in pigment synthesis, pigment degradation, a $C$. sativus no conteúdo de ClA e ChlB. O conteúdo de $\mathrm{ClA}$ de $C$. sativus exposto a suspensões do compósito na concentração de $10 \mathrm{~g} / \mathrm{L}$ mostrou uma redução com diferença significativa $(\mathrm{p}<0,05)$ para $\mathrm{CA} 6 \mathrm{AgB}$ (redução de 52\%), CA12AgB (redução de 44\%) e CA12AgS (redução de 31\%) quando comparado ao controle. Resultados similares foram encontrados para Crambe abyssinica (59), Oryza sativa L. (60) com inibição da síntese de ClB, e Lycopersicon esculentum (61) com inibição da síntese tanto da ClA quanto da $\mathrm{ClB}$, e Physalis peruviana $L$. com redução da clorofila total (62) quando expostas a nanopartículas de prata. $\mathrm{O}$ teor de clorofila, que atua como um biomarcador da actividade fotossintética de uma planta, pode ser reduzido quando exposto a metais. O conteúdo reduzido de clorofila indica uma síntese de clorofila alterada, que pode ter sérias implicações na síntese de material alimentar orgânico (63). A diminuição do conteúdo de clorofila nos tecidos de plantas tratadas com metal depende de vários factores, como distúrbios na síntese de 
and direct inhibition of the enzymatic steps coupled with chlorophyll biosynthesis $(64,65)$.

\section{Cytotoxicity}

The cytotoxicity of treated and untreated $C$. sativus was studied by root cell viability assay using Evans blue dye. This dye is a marker of membrane cell integrity. Table 4 shows the absorbance of the solutions obtained after staining the root with Evans blue and discoloring with methanol. $C$. sativus treated with composite, at a dose of $10000 \mathrm{mg} / \mathrm{g}$ and the values of the control plants, which had the same ability to fix the Evans blue dye. These results therefore indicate that there is no loss of plasma membrane integrity with exposure to composites, as the values for the treated plants were similar to those of the control plants. These results differed from those of potato seedlings treated with Ag-NP and $\mathrm{AgNO}_{3}$, which showed a significant increase in Evans blue absorption in both treatments (66)

\section{Toxicity of composites to Artemia Salina}

The results for the mortality rate of $A$. salina exposed to different composites at different time intervals ( 24 and $48 \mathrm{~h}$ ) are shown in Table 5. In the positive control, exposure to $\mathrm{K}_{2} \mathrm{Cr}_{2} \mathrm{O}_{7}$ showed $100 \%$ mortality within $24 \mathrm{~h}$. In the groups treated with different composites, the mortality rates after $24 \mathrm{~h}$ ranged from $0-3 \%$. These mortality rates were below $11 \%$ after $48 \mathrm{~h}$, except for that of $\mathrm{AC} 12 \mathrm{AgB}$, which was $15 \%$. The LD50 value for all composites must therefore be greater than the concentration tested $(1000 \mathrm{mg} / \mathrm{L})$.

The results showed that the composites were less toxic when compared to PVP/PEI-coated AgNPs, with mortality rates of about $70 \%$ after 48 exposure at $100 \mathrm{mg} / \mathrm{L}$ dose (67). Toxicity was lower than that reported for chitosan-silver nanoparticle-fluoride composites, with mortality rates above $60 \%$ at a concentration of 1000 $\mathrm{mg} / \mathrm{L}$ (68). Toxicity was lower than that observed for PVP-stabilized AgNP and AgNw with mortality rates of $20 \%$ and $100 \%$, respectively, at a concentration of $100 \mathrm{mg} / \mathrm{L}$ after $48 \mathrm{~h}$ of exposure (69). pigmentos, degradação de pigmentos e inibição directa das etapas enzimáticas associadas à biossíntese de clorofila. $(64,65)$.

\section{Citotoxicidade}

A citotoxicidade de $C$. sativus tratada e não tratada foi estudada por ensaio de viabilidade de células-raiz, utilizando o corante azul de Evans. Este corante é um marcador da integridade das células da membrana. A Tabela 4 mostra a absorbância das soluções obtidas após a coloração da raiz com azul de Evans e a descoloração com metanol. C. sativus tratada com compósito, na dose de $10000 \mathrm{mg} / \mathrm{g}$ e os valores das plantas controle, tiveram a mesma capcacidade de fixar o azul de Evans. Portanto, esses resultados indicam que não há perda da integridade da membrana plasmática com a exposição a compósitos, pois os valores para as plantas tratadas foram semelhantes aos das plantas usadas como controle. Esses resultados foram diferentes dos observados para as mudas de batata tratadas com NPs-Ag e $\mathrm{AgNO}_{3}$, que mostraram um aumento significativo na absorção do azul de Evans nos dois tratamentos (66).

\section{Toxicidade dos compósitos para Artemia Salina}

Os resultados para a taxa de mortalidade de A. salina exposta a diferentes compósitos em diferentes intervalos de tempo ( 24 e 48 h) são mostrados na Tabela 5. No controle positivo, a exposição ao $\mathrm{K}_{2} \mathrm{Cr}_{2} \mathrm{O}_{7}$ mostrou $100 \%$ de mortalidade em $24 \mathrm{~h}$. Nos grupos tratados com diferentes compósitos, as taxas de mortalidade após 24 $\mathrm{h}$ variaram de 0 a $3 \%$. Essas taxas de mortalidade ficaram abaixo de $11 \%$ após $48 \mathrm{~h}$, excepto a do CA12AgB, que foi de $15 \%$. O valor DL50 para todos os compósitos deve ser maior que a concentração testada $(1000 \mathrm{mg} / \mathrm{L})$. Os resultados mostraram que os compósitos eram menos tóxicos quando comparados aos NPs-Ag revestidos com PVP/PEI, com taxas de mortalidade de cerca de 70\% após 48 exposições na dose de $100 \mathrm{mg} / \mathrm{L}$ (67). A toxicidade foi menor do que a relatada para compósitos de nanopartículas de prata-quitosana impregnanda com fluor, com taxas de mortalidade acima de $60 \%$ a uma concentração de 1000 mg/L (68). A toxicidade foi menor do que a observada para NPs-Ag estabilizadas com PVP, com taxas de mortalidade de $20 \%$ e $100 \%$, respectivamente, a uma concentração de $100 \mathrm{mg} / \mathrm{L}$ após 48 h de exposição (69). 
Table 5 - Mortality rate (\%) of Artemia salina nauplii after 24 and 48h exposure with composites at a concentration of $1000 \mathrm{mg} / \mathrm{L}$,

Tabela 5 - Taxa de mortalidade (\%) da Artemia salina nauplii após 24 e 48 h de contato com os compósitos na concentração de $1000 \mathrm{mg} / \mathrm{L}$.

\begin{tabular}{|c|c|c|c|c|c|c|}
\hline & \multicolumn{2}{|c|}{$\begin{array}{l}\text { positive control }^{1} / \\
\text { controle positivo }^{1}\end{array}$} & \multicolumn{2}{|c|}{$\begin{array}{l}\text { negative control }^{2} / \\
\text { controle negativo }^{2}\end{array}$} & \multicolumn{2}{|c|}{$\begin{array}{c}\text { composite exposure / } \\
\text { contato com o compósito }\end{array}$} \\
\hline & $24 \mathrm{~h}$ & $48 \mathrm{~h}$ & $24 \mathrm{~h}$ & $48 \mathrm{~h}$ & $24 \mathrm{~h}$ & $48 \mathrm{~h}$ \\
\hline AC6Ag & $100 \pm 0^{3}$ & $100 \pm 0$ & $2 \pm 4$ & $5 \pm 7$ & $2 \pm 4$ & $11 \pm 6$ \\
\hline $\mathrm{AC} 12 \mathrm{Ag}$ & $100 \pm 0$ & $100 \pm 0$ & $2 \pm 4$ & $5 \pm 7$ & $6 \pm 10$ & $11 \pm 9$ \\
\hline $\mathrm{AC} 25 \mathrm{Ag}$ & $100 \pm 0$ & $100 \pm 0$ & $0 \pm 0$ & $0 \pm 0$ & $2 \pm 4$ & $3 \pm 5$ \\
\hline $\mathrm{AC} 50 \mathrm{Ag}$ & $100 \pm 0$ & $100 \pm 0$ & $0 \pm 0$ & $0 \pm 0$ & $2 \pm 4$ & $6 \pm 7$ \\
\hline AC6AgB & $100 \pm 0$ & $100 \pm 0$ & $2 \pm 4$ & $5 \pm 7$ & $0 \pm 0$ & $3 \pm 7$ \\
\hline $\mathrm{AC} 12 \mathrm{AgB}$ & $100 \pm 0$ & $100 \pm 0$ & $2 \pm 4$ & $5 \pm 7$ & $7 \pm 8$ & $15 \pm 11$ \\
\hline $\mathrm{AC} 25 \mathrm{AgB}$ & $100 \pm 0$ & $100 \pm 0$ & $2 \pm 4$ & $5 \pm 7$ & $3 \pm 5$ & $8 \pm 8$ \\
\hline $\mathrm{AC} 50 \mathrm{AgB}$ & $100 \pm 0$ & $100 \pm 0$ & $2 \pm 4$ & $5 \pm 7$ & $7 \pm 7$ & $10 \pm 10$ \\
\hline AC6AgS & $100 \pm 0$ & $100 \pm 0$ & $0 \pm 0$ & $0 \pm 0$ & $1 \pm 3$ & $7 \pm 7$ \\
\hline $\mathrm{AC} 12 \mathrm{AgS}$ & $100 \pm 0$ & $100 \pm 0$ & $0 \pm 0$ & $0 \pm 0$ & $2 \pm 4$ & $3 \pm 5$ \\
\hline $\mathrm{AC} 25 \mathrm{AgS}$ & $100 \pm 0$ & $100 \pm 0$ & $0 \pm 0$ & $0 \pm 0$ & $0 \pm 0$ & $1 \pm 3$ \\
\hline $\mathrm{AC} 50 \mathrm{AgS}$ & $100 \pm 0$ & $100 \pm 0$ & $0 \pm 0$ & $0 \pm 0$ & $1 \pm 3$ & $3 \pm 5$ \\
\hline
\end{tabular}

${ }^{1} \mathrm{~K}_{2} \mathrm{Cr}_{2} \mathrm{O}_{7}(60 \mathrm{mg} / \mathrm{L}) ;{ }^{2}$ sea water $(\mathrm{NaCl} 38 \mathrm{~g} / \mathrm{L}) ;{ }^{3}($ mean \pm standard deviation $)$

${ }^{1} \mathrm{~K}_{2} \mathrm{Cr}_{2} \mathrm{O}_{7}(60 \mathrm{mg} / \mathrm{L}) ;{ }^{2}$ água do $\operatorname{mar}(\mathrm{NaCl} 38 \mathrm{~g} / \mathrm{L}) ;{ }^{3}$ (media \pm desvio padrão)

\section{Conclusion}

The AC containing silver nanoparticles were prepaed with termite feces using different concentrations of $\mathrm{H}_{2} \mathrm{SO}_{4}$, silver, and different chemical reducers. The characteristics of the composites depend on the conditions used in their preparation. The results show that these composites have good antimicrobial activity, with MICs of $500 \mu \mathrm{g} / \mathrm{mL}$ for AC25Ag, AC25AgB and AC6AgS against $S$. aureus, E. coli and C. albicans, respectively. AC25AgB delayed the growth of $S$. aureus and E. coli by 48 and 32 h, respectively. The phytotoxicity results showed deleterious effects on $C$. sativus germination parameters with composites containing high silver concentrations. The ecotoxicology tests in A. salina demonstrated non-toxicity for all composites in the tested dose. Based on the results above, the AC25AgB composite has the potential to be used in the disinfection of water contaminated with pathogenic microorganisms. More detailed studies on the stability of composites in relation to the release of $\mathrm{Ag}^{+}$or $\mathrm{Ag}^{0}$ are being conducted for a possible application of these composites in the disinfection of water.

\section{Conclusões}

Os CA contendo nanopartículas de prata foram preparados com fezes de cupim usando diferentes concentrações de $\mathrm{H}_{2} \mathrm{SO}_{4}$, prata e diferentes redutores químicos. As características dos compósitos dependem das condições empregadas na sua preparação. Os resultados mostram que esses compósitos apresentam boa actividade antimicrobiana. Com CIM de $500 \mu \mathrm{g} / \mathrm{mL}$ para CA25Ag, CA25AgB e CA6AgS contra a $S$. aureus, E. coli e $C$. albicans, respectivamente. O CA25AgB retardou o crescimento de $S$. aureus e E. coli em 48 e 32 $\mathrm{h}$, respectivamente. Os testes de ecotoxicologia em $A$. salina não monstraram toxicidade dos compósitos na dose testada. Com base nos resultados acima o compósito $\mathrm{CA} 25 \mathrm{AgB}$ apresenta potencial para ser utilizado na desinfecção de água contaminada com microrganismos patogénicos. Estudos mais detalhados sobre a estabilidade dos compósitos com relação a liberação do $\mathrm{Ag}^{+}$ou $\mathrm{Ag}^{0}$ estão sendo conduzidos para uma possível aplicação destes compósitos na desinfecção de água. 


\section{Authors Contributions Statement}

The authors Giovana Manesco and Carla Albertina Demarchi, were responsible for the preparation and characterization of the composites, they were also responsible for the antimicrobial and toxicity tests. The authors Jean Felipe Fossá Calisto and Rafael Martello were responsible for determining silver, supervised by Prof. Dr. Jacir Dal Marco. The studies of antimicrobial activity were supervised by Prof. Dr. Alexandre Bella Cruz. Prof Dr. Clovis Antonio Rodrigues supervised the synthesis, characterization, and cytotoxicity evalution of the composites.

\section{Funding}

This study was financed in part by the Coordenação de Aperfeiçoamento de Pessoal de Nível Superior - Brasil (CAPES) - Finance Code 001 and Conselho Nacional de desenvolvimento Científico e Tecnológico- Brasil (CNPq). The authors thank the Governo do Estado of Santa Catarina for the scholarship of Art. 170 (Giovanna Manesco).

\section{Conflict of Interests}

The authors declare there are no financial and/or personal relationships that could present a potential conflict of interests.

\section{Abbreviations}

AC6 - termite feces, activated with $6 \mathrm{~g}$ de $\mathrm{H}_{2} \mathrm{SO}_{4}$ AC12 - termite feces, activated with $12 \mathrm{~g}$ de $\mathrm{H}_{2} \mathrm{SO}_{4}$ AC25 - termite feces, activated with $25 \mathrm{~g}$ de $\mathrm{H}_{2} \mathrm{SO}_{4}$ AC50 - termite feces, activated with $50 \mathrm{~g}$ de $\mathrm{H}_{2} \mathrm{SO}_{4}$ AC6 Ag - termite feces, activated with $6 \mathrm{~g}$ de $\mathrm{H}_{2} \mathrm{SO}_{4}$, impregnated with Ag nanoparticle without reducing agent

AC12Ag - termite feces, activated with $12 \mathrm{~g}$ de $\mathrm{H}_{2} \mathrm{SO}_{4}$, impregnated with Ag nanoparticle without reducing agent

AC25Ag - termite feces, activated with $25 \mathrm{~g}$ de $\mathrm{H}_{2} \mathrm{SO}_{4}$ ' impregnated with Ag nanoparticle without reducing agent

AC50Ag - termite feces, activated with $50 \mathrm{~g}$ de $\mathrm{H}_{2} \mathrm{SO}_{4}$ impregnated with $\mathrm{Ag}$ nanoparticle without reducing agent

$A C 6 \mathrm{AgB}$ - termite feces, activated with $6 \mathrm{~g}$ de

\section{Declaração sobre as contribuições do autor}

As autoras Giovana Manesco e Carla Albertina Demarchi, foram as responsáveis pela preparação e caracterização dos compósitos, também foram responsáveis pelos testes antimicrobianos e de toxicidade. Os autores Jean Felipe Fossá Calisto e Rafael Martello foram responsáveis pela determinação de prata, orientados pelo Prof. Dr. Jacir Dal Marco. Os estudos de actividade antimicrobiana foram supervisionados pelo Prof. Dr. Alexandre Bella Cruz. O Prof Dr. Clovis Antonio Rodrigues orientou os trabalhos de preparação, caracterização e citotoxicidade dos compósitos.

\section{Financiamento}

Este estudo foi financiado em parte pela Coordenação de Aperfeiçoamento de Pessoal de Nível Superior - Brasil (CAPES) - Código Financeiro 001 e pelo Conselho Nacional de Desenvolvimento Científico e Tecnológico - Brasil (CNPq). Os autores agradecem ao Governo do Estado de Santa Catarina pela bolsa de estudos do art. 170 (Giovanna Manesco).

\section{Conflito de Interesses}

Os autores declaram que não há relações financeiras e/ou pessoais que possam representar um potencial conflito de interesses.

\section{Abreviações}

CA6 - fezes de cupin CA ativado com $6 \mathrm{~g}$ de $\mathrm{H}_{2} \mathrm{SO}_{4}$ CA12 - fezes de cupin CA ativado com $12 \mathrm{~g}$ de $\mathrm{H}_{2} \mathrm{SO}_{4}$ CA25 - fezes de cupin CA ativado com $25 \mathrm{~g}$ de $\mathrm{H}_{2} \mathrm{SO}_{4}$ CA50 - fezes de cupin CA ativado com $50 \mathrm{~g}$ de $\mathrm{H}_{2} \mathrm{SO}_{4}$ CA6Ag-fezes de cupin CA ativado com $6 \mathrm{~g}$ de $\mathrm{H}_{2} \mathrm{SO}_{4}$, inpregnado com nanopartículas de Ag sem agente redutor

CA12Ag - fezes de cupin CA ativado com $12 \mathrm{~g}$ de $\mathrm{H}_{2} \mathrm{SO}_{4}$, inpregnado com nanopartículas de $\mathrm{Ag}$ sem agente redutor

CA25Ag - fezes de cupin CA ativado com $25 \mathrm{~g}$ de $\mathrm{H}_{2} \mathrm{SO}_{4}$, inpregnado com nanopartículas de $\mathrm{Ag}$ sem agente redutor

CA50 Ag - fezes de cupin CA ativado com $50 \mathrm{~g}$ de $\mathrm{H}_{2} \mathrm{SO}_{4}$ inpregnado com nanopartículas de $\mathrm{Ag}$ sem agente redutor

CA6AgB - fezes de cupin CA ativado com $6 \mathrm{~g}$ de $\mathrm{H}_{2} \mathrm{SO}_{4}$ 
$\mathrm{H}_{2} \mathrm{SO}_{4}$ impregnated with $\mathrm{Ag}$ nanoparticle reduced with $\mathrm{NaBH}_{4}$

$A C 12 A g B$ - termite feces, activated with $12 \mathrm{~g}$ de $\mathrm{H}_{2} \mathrm{SO}_{4}$ impregnated with $\mathrm{Ag}$ nanoparticle reduced with $\mathrm{NaBH}_{4}$ $A C 25 \mathrm{AgB}$ - termite feces, activated with $25 \mathrm{~g}$ de $\mathrm{H}_{2} \mathrm{SO}_{4}$ impregnated with $\mathrm{Ag}$ nanoparticle reduced with $\mathrm{NaBH}_{4}$ $A C 50 A g B$ - termite feces, activated with $50 \mathrm{~g}$ de $\mathrm{H}_{2} \mathrm{SO}_{4}$ impregnated with $\mathrm{Ag}$ nanoparticle reduced with $\mathrm{NaBH}_{4}$

AC6AgS - termite feces, activated with $6 \mathrm{~g}$ de H2SO4 impregnated with Ag nanoparticle reduce with sucrose AC12AgS - termite feces, activated with $12 \mathrm{~g}$ de $\mathrm{H} 2 \mathrm{SO} 4$ impregnated with Ag nanoparticle reduce with sucrose AC25AgS - termite feces, activated with $25 \mathrm{~g}$ de $\mathrm{H} 2 \mathrm{SO} 4$ impregnated with Ag nanoparticle reduce with sucrose AC50AgS - termite feces, activated with $50 \mathrm{~g}$ de $\mathrm{H} 2 \mathrm{SO} 4$ impregnated with Ag nanoparticle reduce with sucrose inpregnado com nanopartículas de Ag e reduzido com $\mathrm{NaBH}_{4}$

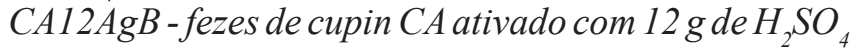
inpregnado com nanopartículas de Ag e reduzido com $\mathrm{NaBH}_{4}$

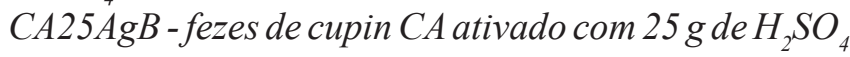
inpregnado com nanopartículas de $\mathrm{Ag}$ e reduzido com $\mathrm{NaBH}_{4}$

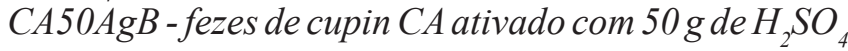
inpregnado com nanopartículas de Ag e reduzido com $\mathrm{NaBH}_{4}$

CA6AgS - fezes de cupin CA ativado com $6 \mathrm{~g}$ de $\mathrm{H}_{2} \mathrm{SO}_{4}$ inpregnado com nanopartículas de Ag e reduzido com sacarose

CA12 AgS-fezes de cupin CA ativado com $12 \mathrm{~g}$ de $\mathrm{H}_{2} \mathrm{SO}_{4}$ inpregnado com nanopartículas de $\mathrm{Ag}$ e reduzido com sacarose

CA25AgS - fezes de cupin CA ativado com $25 \mathrm{~g}$ de $\mathrm{H}_{2} \mathrm{SO}_{4}$ impregnated inpregnado com nanoparticulas de Ag e reduzido com sacarose

CA50AgS - fezes de cupin CA ativado $50 \mathrm{~g}$ de $\mathrm{H}_{2} \mathrm{SO}_{4}$ inpregnado com nanopartículas de Ag e reduzido com sacarose 


\section{References / Referências}

1. Syafiuddin A, Salmiati S, Hadibarata T, Kueh ABH, Salim MR, Zaini MAA. Silver Nanoparticles in the Water Environment in Malaysia: Inspection, characterization, removal, modeling, and future perspective. Sci Reports, 2018;8(1): 1-15.

2. Panáček A, Smékalová M, Večeřová R, Bogdanová K, Röderová M, Kolář M, Kilianová M, Hradilová Š, Froning JP, Havrdová M, Prucek R, Zbořil R, Kvítek L. Silver nanoparticles strongly enhance and restore bactericidal activity of inactive antibiotics against multiresistant Enterobacteriaceae. Colloid Surface B. 2016;142: 392-399.

3. Booshehri AY, Wang R, Xu R. Simple method of deposition of CuO nanoparticles on a cellulose paper and its antibacterial activity. Chem Eng J. 2015; 262:999-1008.

4. Akhigbe L, Ouki S, Saroj D. Disinfection and removal performance for Escherichia coli and heavy metals by silver-modified zeolite in a fixed bed column. Chem Eng J. 2016;295: 92-98.

5. Park SJ, Ko YS, Jung H, Lee C, Woo K, Ko GP. Disinfection of waterborne viruses using silver nanoparticle-decorated silica hybrid composites in water environments. SciTotal Environ. 2018; 625: 477-485.

6. Dixit D, Gangadharan D, Popat KM, Reddy CRK, Trivedi M, Gadhavi DK. Synthesis, characterization and application of green seaweed mediated silver nanoparticles (AgNPs) as antibacterial agents for water disinfection. Water Sci Technol. 2018;78(1):235-246.

7. World Health Organization, Drinking-water. https://www.who.int/news-room/fact-sheets/detail/drinking-water, 2018 (accessed 14 April 2019 ).

8. Fan M, Gong L, Huang Y, Wang D, Gong Z. Facile preparation of silver nanoparticle decorated chitosan cryogels for point-of-use water disinfection. Sci Total Environ. 2018;613-614:1317-1323.

9. Durán N, Durán M, de Jesus, MB, Seabra AB, Fávaro WJ, Nakazato G. Silver nanoparticles: A new view on mechanistic aspects on antimicrobial activity. Nanomed-Nanotechnol. 2016;12(3):789-799.

10. Biswas P, Bandyopadhyaya R. Water disinfection using silver nanoparticle impregnated activated carbon: Escherichia coli cell-killing in batch and continuous packed column operation over a long duration. Water Res. 2016;100:105-115.

11. Panáček A, Kvítek L, Smékalová M, Večeřová R, Kolář M, Röderová M, Dyčka F, Šebela M, Prucek R, Tomanec O, Zbořil R. bacterial resistance to silver nanoparticles and how to overcome it. Nat Nanotech., 2018; 13(1): 65-7.

12. Prashantha Kumar TKM, Mandlimath TR, Sangeetha P, Sakthivel P, Revathi SK, Ashok Kumar SK, Sahoo SK Highly efficient performance of activated carbon impregnated with $\mathrm{Ag}, \mathrm{ZnO}$ and $\mathrm{Ag} / \mathrm{ZnO}$ nanoparticles as antimicrobial materials. RSC Advances, 2015;5(130):108034-108043.

13. Syafiuddin A, Salmiati, Salim MR, Kueh ABH, Hadibarata T, Nur H. A review of silver nanoparticles: research trends, global consumption, synthesis, properties, and future challenges. J Chin Chem Soc. 2017; 64(7):732-756.

14. Beyene HD, Werkneh AA, Bezabh HK, Ambaye TG. Synthesis paradigm and applications of silver nanoparticles (AgNPs), a review. Sust Mater Technol. 2017;13: 18-23.

15. Akter M, Sikder MT, Rahman MM, Ullah AKMA, Hossain KFB, BanikS, Hosokawa T, Saito T, Kurasaki M. A systematic review on silver nanoparticles-induced

16. Mo, J., Yang, Q., Zhang, N., Zhang, W., Zheng, Y., Zhang, Z.: A review on agro-industrial waste (AIW) derived adsorbents for water and wastewater treatment. J. Environ. Manage. 218; 227:395-405.

17. Altintig E, Arabac G, Altundag H. Preparation and characterization of the antibacterial efficiency of silver loaded activated carbon from corncobs. Sur Coat Technol. 2016; 304:63-67.

18. Kumar TKMP, Mandlimath TR, Sangeetha P, Sakthivel P, Revathi SKS, Kumar KA, Sahoo SK. Highly efficient performance of activated carbon impregnated with $\mathrm{Ag}, \mathrm{ZnO}$ and $\mathrm{Ag} / \mathrm{ZnO}$ nanoparticles as antimicrobial materials. RSC Adv. 2014;5: 108034-108043.

19. Kim MH, Cho D, Kwon OH, Park WH. Thermal fabrication and characterization of Ag nanoparticle-activated carbon composites for functional wound-dressing additives. J Alloys Compd. 2018;735:2670-2674.

20. Altintig E, Arabac G, Altundag H. Preparation and characterization of the antibacterial efficiency of silver loaded activated carbon from corncobs. Sur Coat Technol. 2016; 304:63-67.

21. Gonçalves SPC, Strauss M, Delite FS, Clemente Z, Castro VL, Martinez DST. Activated carbon from pyrolysed sugarcane bagasse: Silver nanoparticle modification and ecotoxicity assessment. Sci Total Environ. 2015;565: 833-840.

22. Ortiz-Ibarra H, Torres-Vitela R, Gómez-Salazar S, Casillas N, Ponce de León C, Walsh FC. Enhancement of antibterial efficiency at silver electrodeposited on coconut shell activated carbon by modulating pulse frequency. J Solid St Electroch., 2018;22(3):749-759.

23. Sudhakar P, Soni H. Catalytic reduction of Nitrophenols using silver nanoparticles-supported activated carbon derived from agro-waste. J Environ Chem Eng. 2018;6(1):28-36.

24. Marková Z, Šišková K, Filip J, Šafářová K, Prucek R, Panáček A, Kolář M, Zbořil R. Chitosan-based synthesis of magnetically-driven nanocomposites with biogenic magnetite core, controlled silver size, and high antimicrobial activity. Green Chem., 2012;14(9): 2550-2558.

25. Nguyen NT, Tran DL, Nguyen DC, Nguyen TL, Ba TC, Nguyen BH, Ba TD, Pham NH, Nguyen DT, Tran TH, Pham GD. Facile synthesis of multifunctional $\mathrm{Ag} / \mathrm{Fe}_{3} \mathrm{O}_{4}-\mathrm{CS}$ nanocomposites for antibacterial and hyperthermic applications. Curr App Phys. 2015;15(11): 1482-1487.

26. Filippo E, Serra A, Buccolieri A, Manno D. Green synthesis of silver nanoparticles with sucrose and maltose: Morphological and structural characterization. J Non-Cryst Solids. 2010;356(6-8): 344-350.

27. Sarma J, Mahiuddin S. Specific ion effect on the point of zero charge of $\alpha$-alumina and on the adsorption of 3,4-dihydroxybenzoic acid onto $\alpha$-alumina surface. Colloids and Surfaces A. 2014; 457(1): 419-424

28. Yukselen Y, Kaya A. Suitability of the methylene blue test for surfCAe area, cation exchange capcacity and swell potential determination of clayey soils. Eng Geol. 2008;102(1-2): 38-45.

29. ElShafei GMS, ElSherbiny IMA, Darwish AS, Philip CA. Silkworms' feces-based activated carbons as cheap adsorbents for removal of cadmium and methylene blue from aqueous solutions. Chem Eng Res Design. 2014;92(3): 461-470.

30. Zhou E, He Y, Ma X, Liu G, Huang Y, Chen C, Wang W. Study of the combination of sulfuric acid treatment and thermal regeneration of spent powdered activated carbons from decolourization process in glucosamine production. Chem Eng Proc. 2017;121: 224-231.

31. CLSI Methods for dilution antimicrobial susceptibility tests for bacteria that grow aerobically, approved standart -Tenth edition. CLSI document M07-A10. Wayne, PA: Clínical and Laboratory Standarts Institute. 2015.

32. Beltrami M, Rossi D, Baudo R. Phytotoxicity assessment of Lake Orta sediments. Aquat Eco Healt Manag., 1999;2(4):391-401.

33. Lichtenthaler HK. Chlorophylls and carotenoids: Pigments of photosynthetic biomembranes. Met in Enzym. 1987;148(C): 350-382.

34. Iannone MF, Groppa MD, de Sousa ME, Fernández van Raap MB, Benavides MP. Impact of magnetite iron oxide nanoparticles on wheat (Triticum aestivum L.) development: Evaluation of oxidative damage. Environ Exp Bot. 2016;131:77-88.

35. Libralato, G. The case of Artemia spp. in nanoecotoxicology. Mar Environ Res. 2014;101(1):38-43. 
36. Gerçel Ö, Özcan A, Özcan AS, Gerçel HF. Preparation of activated carbon from a renewable bio-plant of Euphorbia rigida by $\mathrm{H}_{2} \mathrm{SO}_{4}$ activation and its adsorption behavior in aqueous solutions. Appl. Surf. Sci. 2007;253(11): 4843-4852.

37. Cox M, EI-Shafey EI, Pichugin AA, Appleton Q. Preparation and characterisation of a carbon adsorbent from flax shive by dehydration with sulfuric acid. J Chem Technol Biotech 1999;74(11): 1019-1029.

38. Chahm T, Souza LF, Santos NR, Silva BA, Rodrigues CA. Use of chemically activated termite feces a low-cost adsorbent for the adsorption of norfloxacin from aqueous solution. Water SciTechnol. 2019;79(2): 291-301.

39. Hamed MM, Ali MMS, Holiel M. Preparation of activated carbon from doum stone and its application on adsorption of 60Co and 152+154Eu: Equilibrium, kinetic and thermodynamic studies. J Environ Rad. 2016;164:113-124.

40. Jiang Z, Liu Y, Sun X, Tian F, Sun F, Liang C, You W, Han C, Li C. CAtivated carbons chemically modified by concentrated H2SO4 for the adsorption of the pollutants from wastewater and the dibenzothiophene from fuel oils. Langmuir, 2003;19(3): 731-736.

41. Karagöz S, Tay T, Ucar S, Erdem M. Activated carbons from waste biomass by sulfuric acid activation and their use on methylene blue adsorption. Bioresource Technol. 2008;99(14): 6214-6222.

42. Brudey T, Largitte L, Jean-Marius C, Tant T, Dumesnil PC, Lodewyckx P. Adsorption of lead by chemically activated carbons from three lignocellulosic precursors. J Anal Appl Pyr. 2016;120:450-463.

43. Bohli T, Ouederni A. Improvement of oxygen-containing functional groups on olive stones activated carbon by ozone and nitric acid for heavy metals removal from aqueous phase. Environ Sci Pol Res. 2016;23(16): 15852-15861.

44. Arevalo-Fester J. Efficiency study of silver nanoparticles (AgNPs) supported on granular activated carbon against Escherichia coli. J Nanomed Res. 2014;1(2):1-5.

45. Jawad AH, Rashid RA, Ishak MAM, Wilson LD. Adsorption of methylene blue onto activated carbon developed from biomass waste by H2SO4 activation: kinetic, equilibrium and thermodynamic studies. Desalin Water Treat. 2016;57(52):25194-25206.

46. Adio SO, Rana A, Chanabsha B, BoAli AAK, Essa M, Alsaadi A. Silver nanoparticle-loaded activated carbon as an adsorbent for the removal of mercury from arabian gas-condensate. Arab J Sci Eng. 2019;44(7): 6285-6293.

47. Ewais HA, Obaid AY. Adsorption characteristics of toxic chromium(VI) from aqueous media onto nanosized silver nanoparticles-treated activated carbon. Sep Sci Technol. 2019;54(4):494-506.

48. Veisi H, Kavian M, Hekmati M, Hemmati S. Biosynthesis of the silver nanoparticles on the graphene oxide's surface using Pistacia atlantica leaves extract and its antiacterial activity against some human pathogens. Polyhedron, 2019;161: 338-345.

49. Xiu Z, Ma J, Alvarez PJJ. Differential effect of common ligands and molecular oxygen on antimicrobial activity of silver nanoparticles versus silver ions. Environ Sci Technol. 2011;45: 9003-9008.

50. Sun Q, Cai X, Li J, Zheng M, Chen Z, Yu CP. Green synthesis of silver nanoparticles using tea leaf extract and evaluation of their stability and antibacterial activity. Colloids and Surfaces A. 2014;444:226-231.

51. Dat MN, Linh VNP, Huy LA, Huong, NT, Tu TH, Phuong NTL, Nam HM, Thanh MP, Hieu NH. Fabrication and antibacterial activity against Pseudomonas aeruginosa and Staphylococcus aureus of silver nanoparticle decorated reduced graphene oxide nanocomposites. Mater Technol. 2019;34(7):369-375.

52. Wang W, Xiao K, He T, Zhu L Synthesis and characterization of Ag nanoparticles decorated mesoporous sintered activated carbon with antibacterial and adsorptive properties J Alloys Comp. 2015; 647:1007-1012.

53. Tuan TQ, Son NV, Dung HTK, Luong NH, Thuy BT, Anh NTV, Hoa ND, Hai NH. Preparation and properties of silver nanoparticles loaded in activated carbon for biological and environmental applications. J Hazard Mat. 2011;192(3):1321-1329.

54. Yang F.C, Wu KH, Liu MJ, Lin WP, Hu MK. Evaluation of the antibacterial efficacy of bamboo charcoal/silver biological protective material. Mat Chem Phys. 2009;113(1):474-479.

55. Cui J, Yang Y, Hu Y, Li, F Rice husk based porous carbon loaded with silver nanoparticles by a simple and cost-effective approach and their antibacterial activity. J Colloid Interf Sci. 2015;455:117-124.

56. Cui J, Hu C, Yang Y, Wu Y, Yang L, Wang Y, Liu Y, Jiang Z. Facile fabrication of carbonaceous nanospheres loaded with silver nanoparticles as antibacterial materials. J Mat Chem. 2012;22(16): 8121-8126.

57. Barrena R, Casals E, Colón J, Font X, Sánchez A,Puntes V. Evaluation of the ecotoxicity of model nanoparticles. Chemosphere, 2009;75(7):850-857.

58. Tripathi A, Liu S, Singh PK, Kumar N, Pandey AC, Tripathi DK, Chauhan DK, Sahi S. Differential phytotoxic responses of silver nitrate (AgNO3) and silver nanoparticle (AgNps) in Cucumis sativus L. Plant Gen. 2017;11: 255-264.

59. Ma C, Chhikara S, Minocha R, Long S, Musante C, White JC, Xing B, Dhankher OP. Reduced silver nanoparticle phytotoxicity in Crambe abyssinica with enhanced glutathione production by overexpressing bacterial $\gamma$-glutamylcysteine synthase. Environ Sci Technol. 2015; 49:10117-10126.

60. Mirzajani F, Askari H, Hamzelou S, Farzaneh M, Ghassempour A. Effect of silver nanoparticles on Oryza sativa L. And its rhizosphere bacteria. Ecotox Environ Safe. 2013; 88:48-54

61. Songu, JH, Waldman B, Roh J, Kim Y, Yi J, Lee EJ. Functional analyses of nanoparticle toxicity: A comparative study of the effects of TiO ${ }_{2}$ and $\mathrm{Ag}$ on tomatoes (Lycopersicon esculentum). Ecotox Environ Safe. 2013;93:60-67.

62. Timoteo CO, Paiva R, Reis MV, Claro PIC, Ferraz LM, Marconcini JM, Oliveira JE. In vitro growth of Physalis peruviana L. affected by silver nanoparticles. 3 Biotech, 2019; 9(4):145-150.

63. Rani PU, Yasur J, Loke KS, Dutta, D. Effect of synthetic and biosynthesized silver nanoparticles on growth, physiology and oxidative stress of water hyacinth: Eichhornia crassipes (Mart) Solms. Acta Phys Plant. 2016;38(2):1-9.

64. Nair PMG, Chung IM Physiological and molecular level effects of silver nanoparticles exposure in rice (Oryza sativa L.) seedlings. Chemosphere. 2014; 112:105-113.

65. Karimi J, Mohsenzadeh S. Physiological effects of silver nanoparticles and silver nitrate toxicity in Triticum aestivum. Iran J Sci Technol Trans. A 2017;41(1):111-120.

66. Homae MB, Ehsanpour AA. Silver nanoparticles and silver ions: Oxidative stress responses and toxicity in potato (Solanum tuberosum L) grown in vitro. Hort. Environ. Biotechnol. 2016;57(6):544-553.

67. Lacave JM, Fanjul Á, Bilbao E, Gutierrez N, Barrio I, Arostegui I, Cajaraville MP, Orbea A. Acute toxicity, bioaccumulation and effects of dietary transfer of silver from brine shrimp exposed to PVP/PEI-coated silver nanoparticles to zebrafish. Comp Biochem Physiol C.2017;199: 69-80.

68. Freire PLL, Albuquerque AJR, Farias IAP, Silva TG, Aguiar JS, Galembeck A, Flores MAP, Sampaio FC, Stamford TCM, Rosenblatt A. Antimicrobial and cytotoxicity evaluation of colloidal chitosan - silver nanoparticles - fluoride nanocomposites. Inter J Biol Macromol. 2016;93:896-903.

69. An HJ, Sarkheil M, Park HS, Yu IJ, Johari SA. Comparative toxicity of silver nanoparticles (AgNPs) and silver nanowires (AgNWs) on saltwater microcrustacean, Artemia salina. Comp Biochem Phys C. 2019;218:62-69. 